Research article

\title{
The partial root-zone saline irrigation system and antioxidant responses in tomato plants
}

\author{
Rita de Cássia Alves ${ }^{\mathrm{a}}$, Ana Santana de Medeiros ${ }^{\mathrm{b}}$, Mayara Cristina Malvas Nicolau ${ }^{\mathrm{a}}$, \\ Antônio Pizolato Neto ${ }^{c}$, Francisco de Assis oliveira ${ }^{\mathrm{b}}$, Leonardo Warzea Lima ${ }^{\mathrm{d}}$, Tiago Tezotto ${ }^{\mathrm{a}}$, \\ Priscila Lupino Gratão ${ }^{\mathrm{a}, *}$ \\ a Universidade Estadual Paulista (UNESP), Faculdade de Ciências Agrárias e Veterinárias, Jaboticabal. Departamento de Biologia Aplicada à Agropecuária, CEP 14884- \\ 900, SP, Brazil

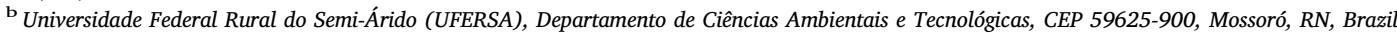 \\ ${ }^{\mathrm{c}}$ Universidade Estadual Paulista (UNESP), Faculdade de Ciências Agrárias e Veterinárias, Jaboticabal. Departamento de Produção Vegetal, CEP 14884-900, SP, Brazil \\ d Colorado State University, Department of Biology, Fort Collins, CO, 80523, USA
}

\section{A R T I C L E I N F O}

\section{Keywords:}

Solanum lycopersicum L

Salinity

Oxidative stress

Partial root-zone irrigation

\begin{abstract}
A B S T R A C T
Salinity is a limiting factor that can affect plant growth and cause significant losses in agricultural productivity. This study provides an insight about the viability of partial root-zone irrigation (PRI) system with saline water supported by a biochemical approach involving antioxidant responses. Six different irrigation methods using low and high salt concentrations (S1-0.5 and S2-5.0 dS m ${ }^{-1}$ ) were applied, with or without PRSI, so that one side of the root-zone was submitted to saline water while the other side was low salinity water irrigated. The results revealed different responses according to the treatments and the PRSI system applied. For the treatments T1, T2 and T3, the PRSI was not applied, while T4, T5 and T6 treatments were applied with PRSI system. Lipid peroxidation, proline content, and activities of SOD, CAT, APX, GR and GSH in tomato plants subjected to PRSI system were analyzed. Plant growth was not affected by the salt concentrations; however, plants submitted to high salt concentrations showed high MDA content and $\mathrm{Na}^{+}$accumulation when compared to the control plants. Plants submitted to treatments T4, T5 and T6 with PRSI system exhibited lower MDA compared to the control plants (T1). Proline content and activities of SOD, CAT, APX, GR and GSH content were maintained in all treatments and tissues analyzed, with only exception for APX in fruits and GSH content, in roots. The overall results showed that PRSI system could be an applicable technique for saline water supply on irrigation since plants did not show to be vulnerable to salt stress, supported by a biochemical approach involving antioxidant responses.
\end{abstract}

\section{Introduction}

Agricultural irrigation relies upon the good quality in water supplies for an adequate plant growth and crop production. The water supply for irrigation has become a limiting factor for greenhouse farming due to the use of low quality water, usually with high salt levels, and nonoccurrence of salt washing by the rainwater, as occurs in the crop field (Guedes et al., 2015). Additionally, the use of saline water in a sustainable agricultural irrigation has become a challenge for researchers seeking to improve water management practices in order to achieve a lower environmental impact and a higher yield.

High salinity is a severe limiting factor among all the abiotic stresses, which can negatively affect the crop production (Maskri et al., 2010; Yasar et al., 2016). Abiotic stresses can lead to an enhanced production of reactive oxygen species (ROS) in plants, due to the disruption of cellular homeostasis, causing damage to proteins, DNA, lipids, activation of the programmed cell death (PCD) pathway and ultimately leading to different tissues death (Cuypers et al., 2010; Stolfa et al., 2016; Yasar et al., 2016).

Once formed, the cascade of uncontrolled oxidation reactions by these ROS can be disrupted by enzymatic and non-enzymatic mechanisms to maintain the adequate cell redox state (Gratão et al., 2015; Alves et al., 2017). The primary defense response comprises the activity of antioxidant enzymes such as Superoxide Dismutase (SOD, EC

\footnotetext{
* Corresponding author.

E-mail addresses: cassiaagro-24@outlook.com (R.d.C. Alves), aninhakgb@yahoo.com.br (A.S. de Medeiros), mayara.nicolau@hotmail.com (M.C.M. Nicolau), antoniopizolatoneto@gmail.com (A.P. Neto), thikaoamigao@ufersa.edu.br (F. de Assis oliveira), leonardo.lima@colostaste.edu (L.W. Lima), tiagotezotto@gmail.com (T. Tezotto), plgratao@fcav.unesp.br (P.L. Gratão).
} 
1.15.1.1), which converts the $\mathrm{O}_{2}^{-}$(superoxide radical) into $\mathrm{H}_{2} \mathrm{O}_{2}$ (hydrogen peroxide) (Foyer and Noctor, 2013). Subsequently, $\mathrm{H}_{2} \mathrm{O}_{2}$ may be detoxified to $\mathrm{H}_{2} \mathrm{O}$ by different enzymes such as Glutathione Peroxidase (GPX, EC 1.11.1.9), Ascorbate Peroxidase (APX, EC 1.11.1.11) Catalase (CAT, 1.11.1.6) and other peroxidases (Serkedjieva, 2011; Ismail et al., 2014; Nawaz et al., 2015; Noctor and Foyer, 2016). The ascorbate-glutathione cycle is closed by regeneration of reduced glutathione (GSH) from oxidized glutathione (GSSG) by glutathione reductase (GR, EC 1.6.4.2) using NADPH as a reducing agent (Pompeu et al., 2016).

Moreover, non-enzymatic mechanisms may be also responsible for quenching excessively ROS, such as ascorbate (AsA), flavonoids, carotenoids, glutathione (GSH) and metabolite proline, (Gratão et al., 2005; Ahmad et al., 2010; Szabados and Savouré, 2010; Foyer and Noctor, 2013; Souza et al., 2013; Zouari et al., 2016a; b).

Different researches have been carried out seeking to understand the best management strategy for using saline water in agriculture. In contrast, to date is not yet possible to state which system provides the more adequate use of saline water, in order to assure the proper plant growth and yield (Borghesi et al., 2011; Manai et al., 2014; Parvin et al., 2015).

High concentrations of $\mathrm{NaCl}$ in root-zone can reduce water potential, causing osmotic stress (Abreu et al., 2013; Deinlein et al., 2014; AbdElgawad et al., 2016) which consequently will induce an oxidative stress through the overproduction of ROS (Murshed et al., 2014). The whole plant system can be affected leading to reduced growth and development (Manai et al., 2014).

Therefore, the partial root-zone irrigation (PRI) system has been largely studied in different crop plants. The PRI consists of the root partitioning in two or more sections so that each part receives different solutions (Kang and Zhang, 2004; Liu et al., 2007; Shahnazari et al., 2007). Plants grown under the PRI system are able to maintain its yield and tolerate abiotic stress with low water consumption, in addition its antioxidant defense system can act with effectiveness thus reducing oxidative stress (Kang and Zhang, 2004; Hu et al., 2010; Dai et al., 2014).

The PRI system can be an applicable technique for saline water supply on irrigation, even if the system success appears to be dependent on the salinity level and time exposure of roots to the salts of nutrient solution (Koushafar et al., 2011; Dai et al., 2014; Guedes et al., 2015), because any additional salt stress may induce different physiological responses to drought under PRI irrigation (Kusakabe et al., 2009).

The use of the PRI system can establish itself as a possible alternative for the irrigation management for plants in which the use of saline water can become inevitable for irrigation. In this system, the water potentials for plants with part of the roots at high-salinity can be equalized by water potentials to those plants growing in low-salinity, maintaining transpiration, stomatal conductance and photosynthesis (Bazihizina et al., 2012).

In view of the promising application of the PRI system as well as the economic and sustainable potential for agriculture, this work aimed to present the viability of the PRI with the use of saline water in the irrigation of the tomato, subsidized by the antioxidant systems responses of the crop to stressful-salt conditions.

\section{Material and methods}

\subsection{Experimental area}

The study was carried out at the Environmental and Technological Sciences Department at the "Universidade Federal Rural do Semi-Radio (UFERSA)", in Mossoró, RN, Brazil (latitude: $05^{\circ} 11^{\prime} \mathrm{S}$, longitude: $37^{\circ}$ $20^{\prime} \mathrm{W}$, altitude $18 \mathrm{~m}$ ). The experiment was conducted in an arc-shaped greenhouse, covered with a transparent low density polyethylene (LDPE), with $10 \mathrm{~mm}$ thickness, treated to avoid the ultraviolet radiation effects, with $7 \mathrm{~m}$ wide and $18 \mathrm{~m}$ of length. The side and front walls were made from polyethylene shade cloth, $50 \%$ black, fixed in $0.30 \mathrm{~m}$ reinforced concrete footer.

\subsection{Experimental design}

The experimental design was completely randomized, containing six treatments and four replicates each. Experimental unit consisted of a plastic pot with a capacity of $10 \mathrm{dm}^{-3}$, one-plant-per-pot. The tomato has four distinct phases: from the seeding to transplant (phase I - one to four weeks); from the transplant to the beginning of flowering (phase II - four to six weeks); from the flowering to the beginning of fruit initiation (phase III - five to twelve weeks); and from the fruit development to the end of harvest (phase IV - twelve to eighteen weeks) (Henareh and Hassani, 2014).

The treatments consisted of six different irrigation managements using low $\left(0.5 \mathrm{dS} \mathrm{m}^{-1}\right)$ and high saline $\left(5.0 \mathrm{dS} \mathrm{m}^{-1}\right)$ water, applied with or without the partial root-zone saline irrigation (PRSI). PRSI management has been adopted in different ways during distinct phases, described as follows: T1 - Irrigation with water from the campus supplying network as a control $\left(0.5 \mathrm{dS} \mathrm{m}^{-1}\right)$; $\mathrm{T} 2$ - Irrigation with saline water $\left(5.0 \mathrm{dS} \mathrm{m}^{-1}\right)$; T3 - Alternate irrigation system between these two established salt concentrations ( 0.5 and $\left.5.0 \mathrm{dS} \mathrm{m}^{-1}\right)$, with a cycling period of 15 days for each one; T4* - Irrigation with 0.5 and $5.0 \mathrm{dS} \mathrm{m}^{-1}$, adopting the PRSI system, such that one side of the rootzone was submitted to low saline water $\left(0.5 \mathrm{dS} \mathrm{m}^{-1}\right)$ while the other side was high saline water irrigated $\left(5.0 \mathrm{dS} \mathrm{m}^{-1}\right)$, the PRSI was adopted from the phase II to the phase IV; T5* - Irrigation with the two established salt concentrations ( 0.5 and $5.0 \mathrm{dS} \mathrm{m}^{-1}$ ), adopting the PRSI system in the phase II, whereas each side of the root-zone received both saline water irrigation, with the interchange between low and high saline water during the phase III, thus remaining until the end of phase IV; T6* - Irrigation with the two established salt concentrations $(0.5$ and $5.0 \mathrm{dS} \mathrm{m}^{-1}$ ), adopting the PRSI system in the phase II, whereas each side of the root-zone received both saline water irrigation, with the interchange between low and high saline water every 15 days, remaining until the end of the phase IV. The PRSI system was settled using plastic bags within the pots in order to avoid the pot contamination with salts (Fig. 1).

The $5.0 \mathrm{dS} \mathrm{m}^{-1}$ saline water was obtained by dissolving sodium chloride $(\mathrm{NaCl})$ in water collected in the UFERSA supplying water system. The dissolved $\mathrm{NaCl}$ volume used to acquire this specific EC was determined from an artificial water salinization curve, relating the salt concentration with the EC, based on Richard's differential equation for the movement of water in unsaturated soils (Richards, 1954) (C = 640 . ECa) where $\mathrm{C}$ is the salt concentration $\left(\mathrm{mg} \mathrm{L}^{-1}\right)$ and $\mathrm{ECa}$, the solution electrical conductivity $\left(\mathrm{dS} \mathrm{m}^{-1}\right)$. For this procedure, samples of water from the UFERSA supplying water system were used, considering its natural EC.

\subsection{Plant growth}

The tomato SUPERA F1 belongs to saladette-type hybrids group, and was chosen not only due to its higher yield potential, but also to its short-cycle variety. The main root cutting and the portioning of the remaining roots was performed, in order to have the same root volume in both sides of the pots. Furthermore, these pots were disposed in 4 lines containing 6 pots each, distributed in $1.5 \mathrm{~m}$ spacing among the lines and $0.70 \mathrm{~m}$ between plants. During the first 10 days after the transplanting (DAT), all treatments were irrigated using low saline water, in order to promote a uniform seedlings development. In the period of 11 DAT, the different levels of saline water irrigation were performed, according to the established treatments.

\subsection{Irrigation and fertigation management}

A dripping irrigation system was carried out with microtube 


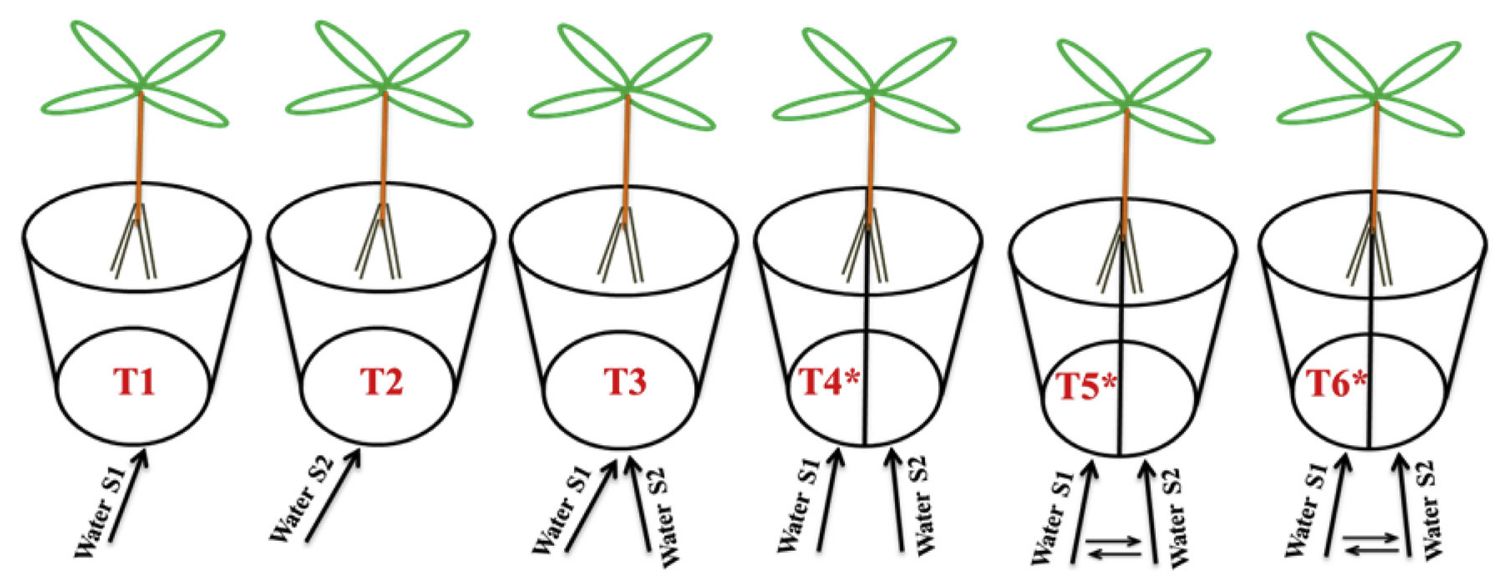

$\mathrm{S} 1=0.5$ e $\mathrm{S} 2=5,0 \mathrm{dS} \mathrm{m}^{-1}$

Fig. 1. Outline of the experimental design.

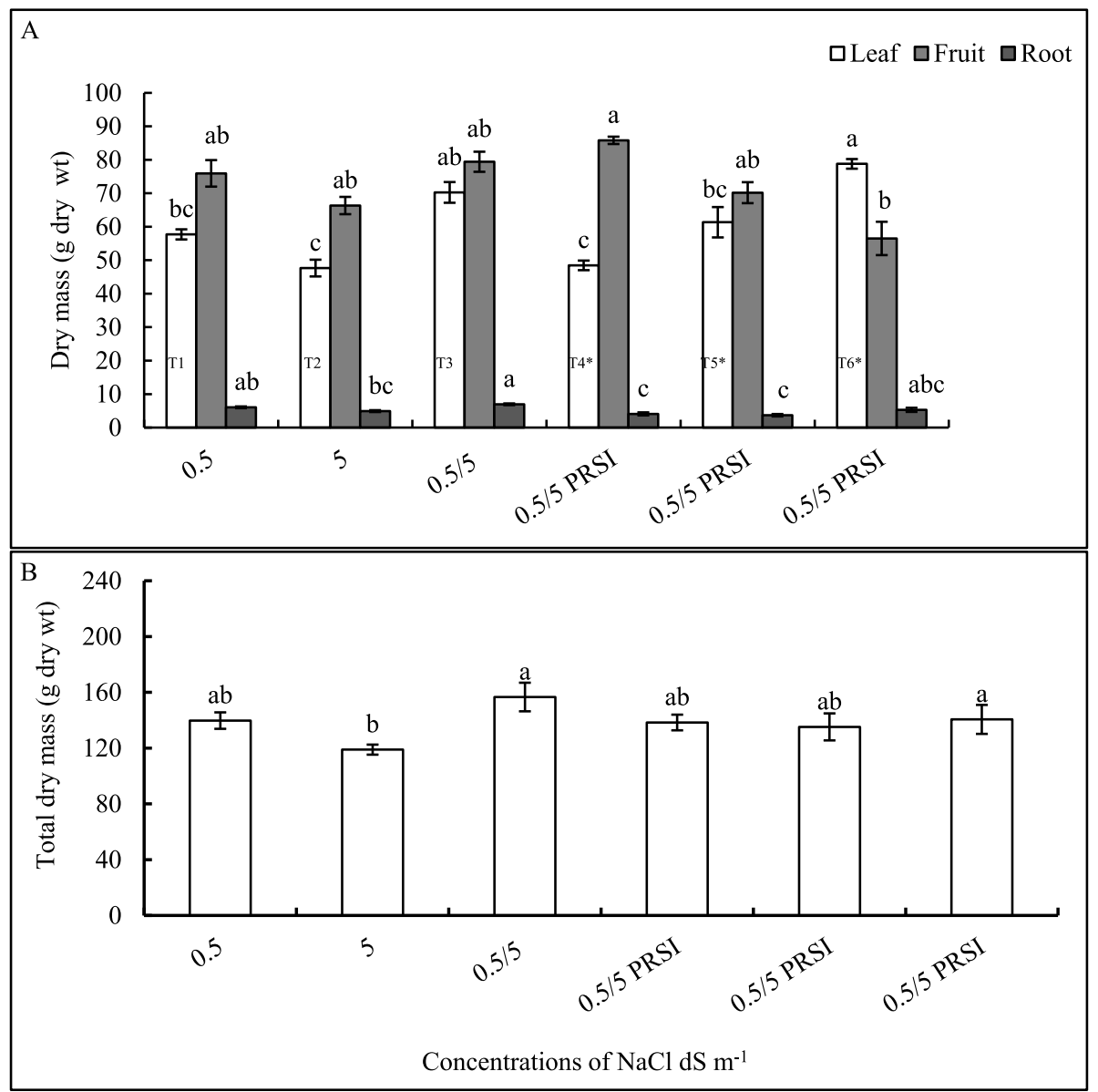

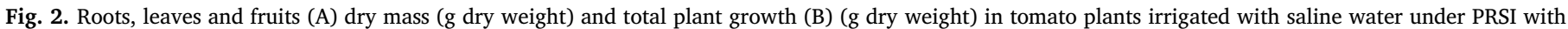
significantly different at $\mathrm{P}<0.05$ by Tukey test.

emitters, which were previously evaluated under regular operation conditions. The emitters were coupled to the $16 \mathrm{~mm}$ sideway lines (polyethylene tubes), in which pressure control microvalves were installed, which were used to apply the proper water volume. An autonomous water irrigation system was applied to each type of water.

The fertilizer application was performed on a daily basis through the irrigation water, according to Miranda et al. (2011) recommendation. Additionally, the following fertilizers were used to prepare the 


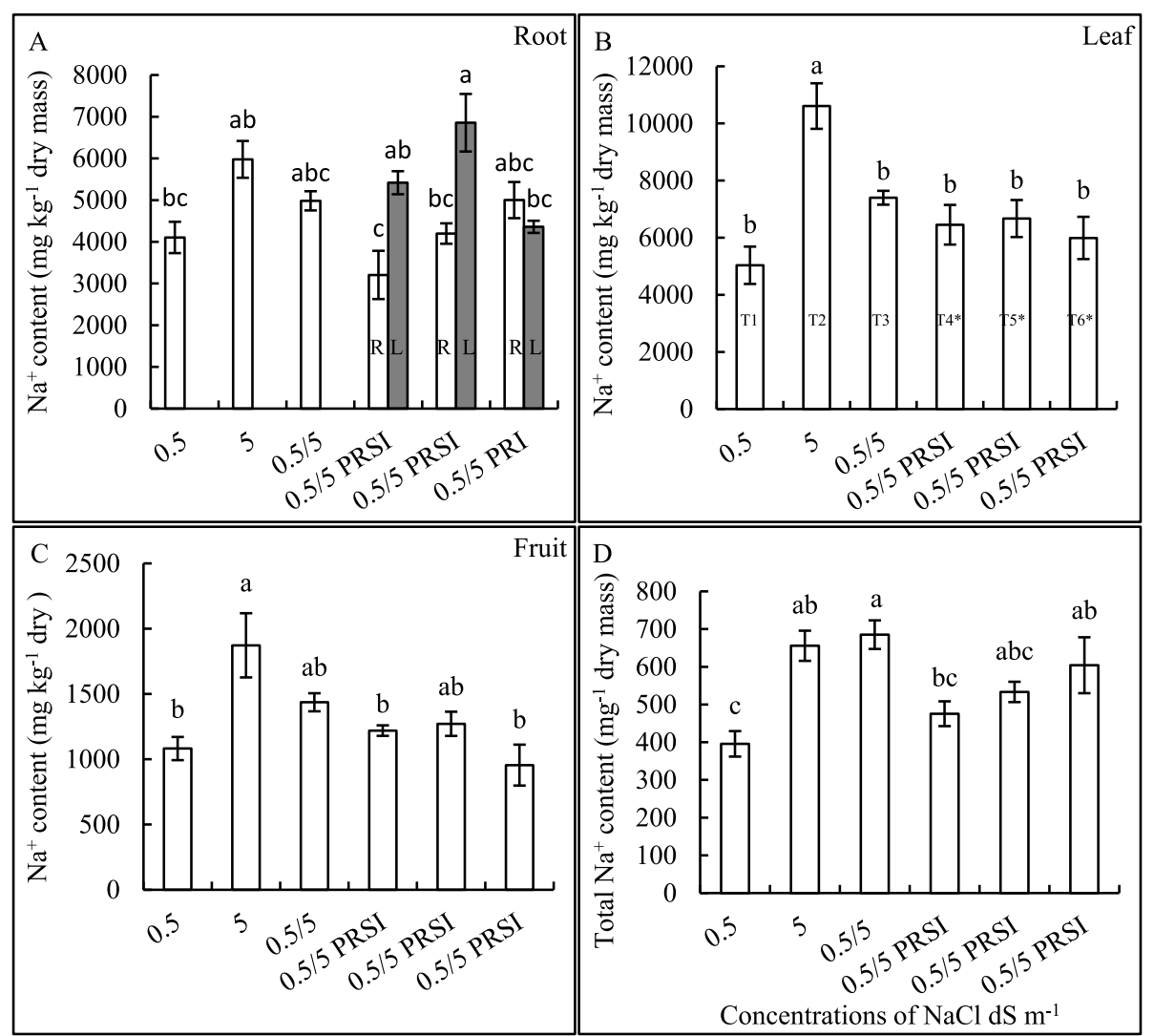

Fig. 3. $\mathrm{Na}^{+}$content in roots (A), leaves (B), fruits (C) and total (D) ( $\mathrm{mg} \mathrm{kg}^{-1}$ dry weight) in tomato plants irrigated with saline water under PRSI with significantly different at $\mathrm{P}<0.05$ by Tukey test, ${ }^{*} \mathrm{R}$ and $\mathrm{L}$ right and left sides of the root.

nutrient solution: calcium nitrate $(1740 \mathrm{~g} / 2000 \mathrm{l})$, potassium nitrate $(606 \mathrm{~g} / 20001)$, potassium sulfate $(348 \mathrm{~g} / 2000 \mathrm{l})$, magnesium sulfate $(650 \mathrm{~g} / 2000 \mathrm{l})$, monopotassium phosphate $(480 \mathrm{~g} / 2000 \mathrm{l})$, iron chelate (94 g/2000 1), manganese sulfate $(7.6 \mathrm{~g} / 2000 \mathrm{l})$, copper sulfate $(3 \mathrm{~g} /$ $2000 \mathrm{l})$, zinc sulfate $(2.8 \mathrm{~g} / 2000 \mathrm{l})$, boric acid $(8.2 \mathrm{~g} / 2000 \mathrm{l})$ and sodium molybdate $(0.26 \mathrm{~g} / 2000 \mathrm{l})$.

\subsection{Growth analysis of plants and accumulation of $\mathrm{Na}^{+}$}

Plants were collected and separated 120 days after the transplanting in leaves, stem, fruit and root and placed in an oven for $72 \mathrm{~h}$ at $70^{\circ} \mathrm{C}$. The dry mass measurements were carried out using an analytical balance accurate to $0.01 \mathrm{~g}$ and the results expressed in $\mathrm{g}_{\text {plant }}{ }^{-1}$.

Assays for the determination of the $\mathrm{Na}^{+}$contents of the plant tissues were performed following digestion with a mixture of nitric and perchloric acids according to Epstein and Bloon (2005). $\mathrm{Na}^{+}$concentrations were measured using a flame photometer (Micronal - B462) and flame atomic absorption spectroscopy with a Perkin Elmer spectrometer model 310, respectively. $\mathrm{Na}^{+}$concentrations are expressed as $\mathrm{mg} \mathrm{kg}^{-1}$ of dry tissue. The accumulation was obtained by the following expression:

$$
\text { Accumulation } \begin{aligned}
\mathrm{Na}^{+} & =\frac{\text { dry weight }(\mathrm{g}) \times \text { concentration }\left(\mathrm{mgkg}^{-1}\right)}{1000} \\
& =m g \text { plant }^{-1}
\end{aligned}
$$

\subsection{Biochemical analysis}

\subsubsection{Lipid peroxidation}

Lipid peroxidation was estimated by the content of thiobarbituric acid reactive substances (TBARS). The concentration of malondialdehyde (MDA) equivalents was calculated using the absorbance coefficient $1.55 \times 10^{-5} \mathrm{~mol}^{-1} \mathrm{~cm}^{-1}$, with readings between 535 and $600 \mathrm{~nm}$ (Gratão et al., 2012). The results are expressed in $\mu \mathrm{moL} / \mathrm{mg}$ fresh tissue (Shimizu et al., 2006).

\subsubsection{Proline content}

Free proline content was measured as described by Gratão et al. (2012). Plant tissues were extracted with $3 \%$ sulphosalicylic acid and the homogenate was centrifuged at $10,000 \times g$ for $15 \mathrm{~min}$ at $4^{\circ} \mathrm{C}$. The supernatant was held for $1 \mathrm{~h}$ in boiling water, $100^{\circ} \mathrm{C}$, by adding $2 \mathrm{~mL}$ of glacial acetic acid and $2 \mathrm{~mL}$ of ninhydrin, to which cold toluene $(4 \mathrm{~mL})$ was added. The absorbance was read at $520 \mathrm{~nm}$ and calculated as $\mu \mathrm{mol}$ $\mathrm{g}^{-1}$ fresh weight against standard proline.

\subsubsection{Enzyme extraction and protein determination}

The following steps were carried out at $4{ }^{\circ} \mathrm{C}$ unless stated otherwise. Leaves, roots and fruits samples were homogenized in buffer volume/ fresh weight $(2: 1)$ in a mortar with a pestle in $100 \mathrm{mM}$ potassium phosphate buffer ( $\mathrm{pH}$ 7.5) containing $1 \mathrm{mM}$ ethylene diaminetetraacetic acid (EDTA), $3 \mathrm{mM}$ DL-dithiothreitol and 5\% (w/v) insoluble polyvinylpolypyrrolidone (Boaretto et al., 2014). The homogenate was centrifuged at $10,000 \times g$ for $30 \mathrm{~min}$ and the supernatant was stored at $-80^{\circ} \mathrm{C}$ prior to SOD, CAT, APX and GR analyses. Protein concentration for all samples was determined by the method of Bradford (1976), using bovine serum albumin as a standard.

2.6.3.1. Superoxide dismutase (SOD) assay. The activity of SOD was determined by the nitrotetrazolium blue chloride method (Alves et al., 2017). The assay medium contained $50 \mathrm{mM}$ sodium PBS buffer ( $\mathrm{pH}$ 7.8), $50 \mathrm{mM}$ methionine, $10 \mathrm{mM}$ ethylene diaminetetraacetic acid (EDTA), $1 \mathrm{mM}$ nitrotetrazolium blue chloride and $0.1 \mathrm{mM}$ riboflavin, with non-enzyme solution as control. One unit of enzyme activity was defined as the amount of enzyme required to inhibit the 


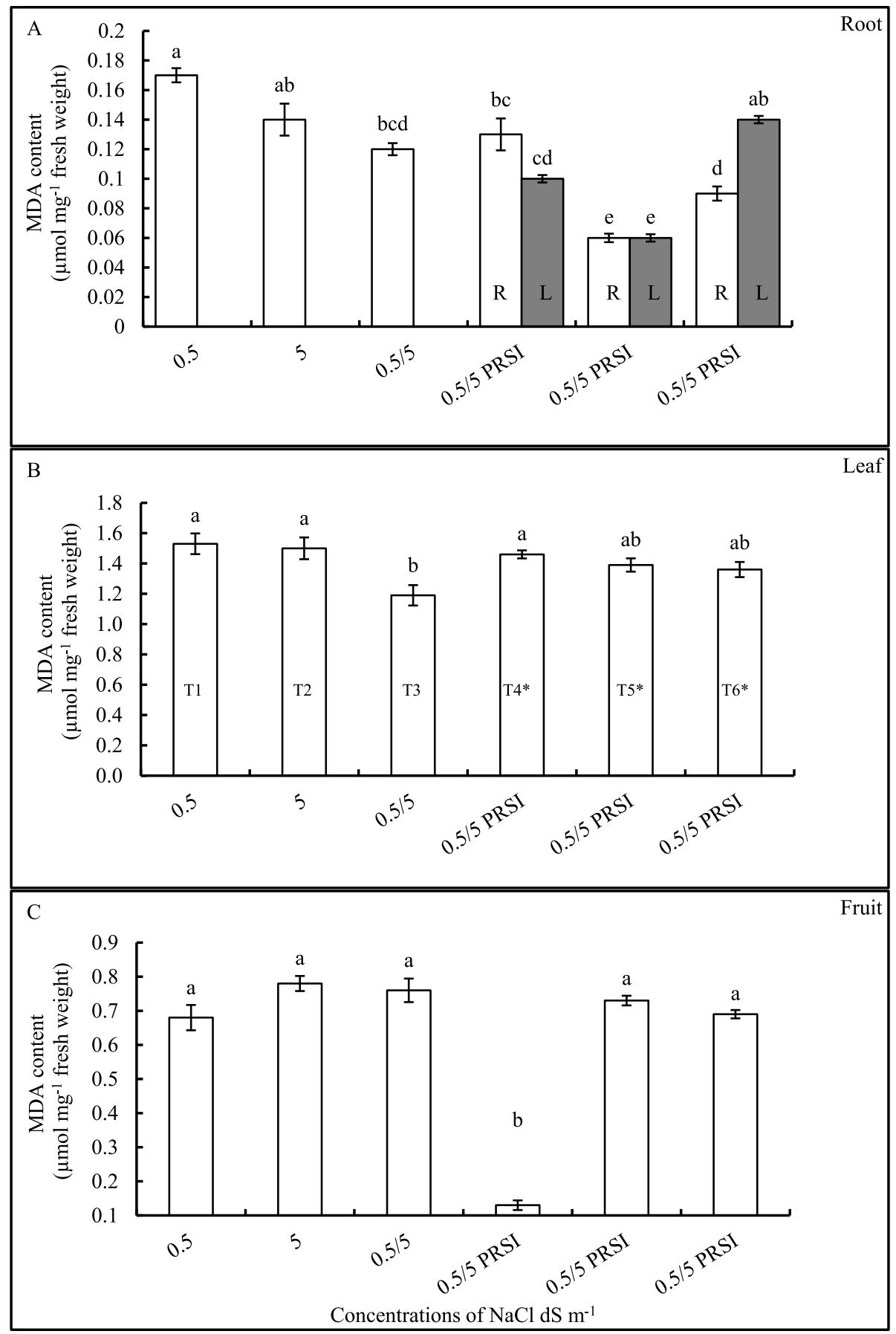

Fig. 4. MDA content in roots (A), leaves (B) and fruits (C) ( $\mu \mathrm{mol} \mathrm{mg}^{-1}$ fresh weight) of tomato plants irrigated with saline water under PRSI with significantly different at $\mathrm{P}<0.05$ by Tukey test, * $\mathrm{R}$ and $\mathrm{L}$ represented right and left sides of the root.

nitrotetrazolium blue chloride reduction by $50 \%$ at $560 \mathrm{~nm}$. SOD activity was expressed as $\mathrm{U}_{\text {SOD }} \mathrm{mg}^{-1}$ protein.

2.6.3.2. Catalase (CAT) assay. Catalase activity (CAT) was assayed spectrophotometrically at $25^{\circ} \mathrm{C}$ in a reaction mixture containing $1 \mathrm{~mL}$ of $100 \mathrm{mM}$ potassium phosphate buffer ( $\mathrm{pH} 7.5$ ), containing $25 \mathrm{~mL}$ $\mathrm{H}_{2} \mathrm{O}_{2}$ (30\% solution). The activity was determined by monitoring the decomposition of $\mathrm{H}_{2} \mathrm{O}_{2}$ at $240 \mathrm{~nm}$ over $1 \mathrm{~min}$ (Cia et al., 2012). CAT

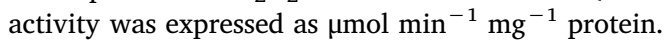

2.6.3.3. Ascorbate peroxidase (APX) assay. Ascorbate peroxidase (APX) activity was assayed spectrophotometrically in a reaction containing $50 \mathrm{mM}$ potassium phosphate buffer $(\mathrm{pH} 7.0), 0.5 \mathrm{mM}$ ascorbate,
$0.1 \mathrm{mM}$ EDTA and $0.1 \mathrm{mM} \mathrm{H}_{2} \mathrm{O}_{2}$ (Gratão et al., 2012). APX activity was determined by monitoring the rate of ascorbate oxidation at $290 \mathrm{~nm}$ at $30^{\circ} \mathrm{C}$. APX activity was expressed as $\mu \mathrm{mol}$ ascorbate $\mathrm{min}^{-1}$ $\mathrm{mg}^{-1}$ protein.

2.6.3.4. Glutathione reductase (GR) assay. Glutathione reductase (GR) activity was determined spectrophotometrically at $30^{\circ} \mathrm{C}$ in a mixture consisting of $100 \mathrm{mM}$ potassium phosphate buffer ( $\mathrm{pH} 7.5$ ), containing $1 \mathrm{mM}$ 5.500-dithiobis (2-nitrobenzoic acid), $1 \mathrm{mM}$ GSSG and $0.1 \mathrm{mM}$ NADPH. The rate of reduction of GSSG was followed by monitoring the increase in absorbance at $412 \mathrm{~nm}$ over $2 \mathrm{~min}$ (Carvalho et al., 2013). GR activity was expressed as $\mu \mathrm{mol} \mathrm{min}^{-1} \mathrm{mg}^{-1}$ protein. 


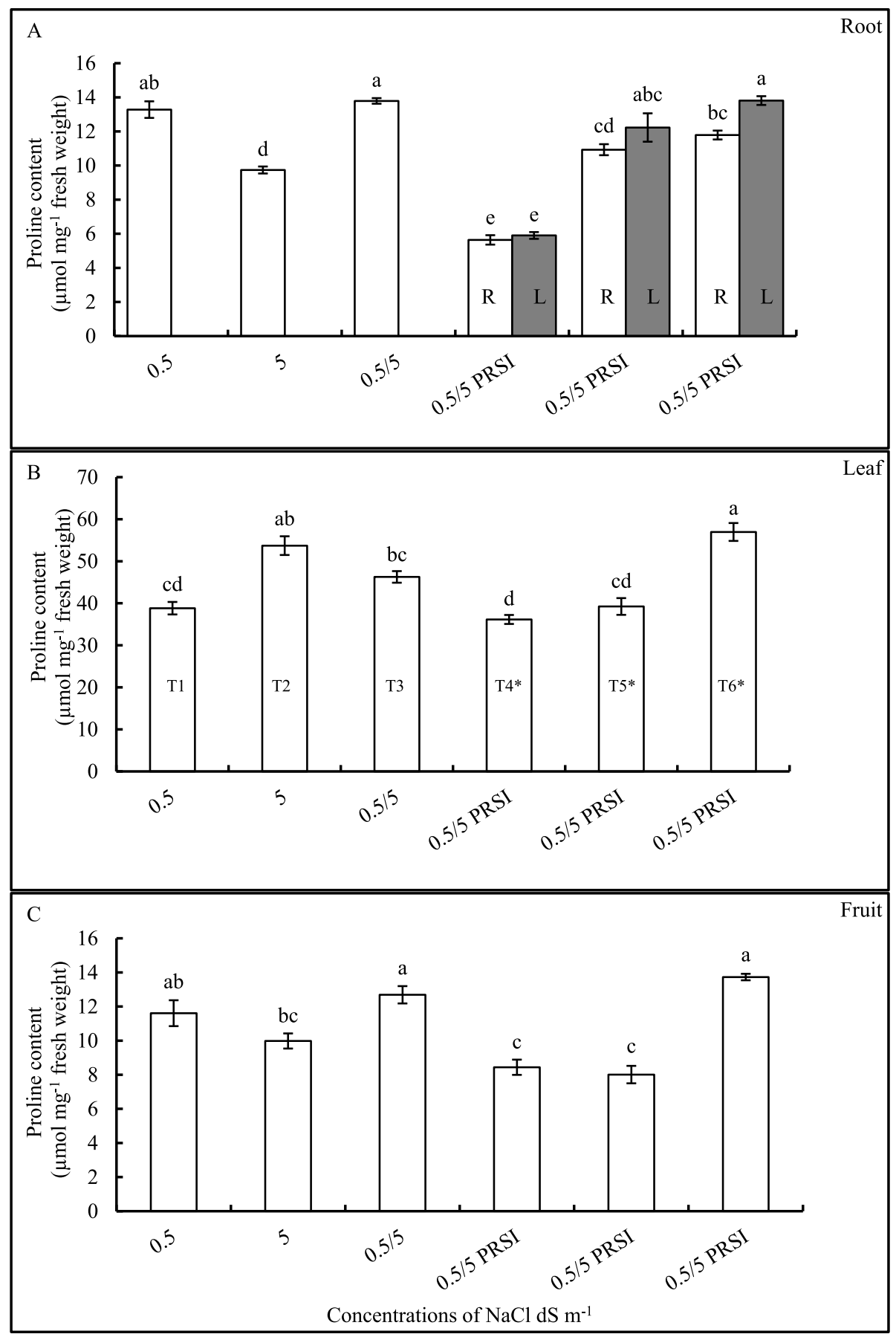

Fig. 5. Proline content in roots (A), leaves (B) and fruits (C) ( $\mu \mathrm{mol} \mathrm{mg}^{-1}$ fresh weight) of tomato plants irrigated with saline water under PRSI with significantly different at $\mathrm{P}<0.05$ by Tukey test, * $\mathrm{R}$ and $\mathrm{L}$ represented right and left sides of the root.

2.6.3.5. Reduced glutathione (GSH) content. The reduced Glutathione (GSH) content was assayed using 5,5"dithiobis (2-nitrobenzoic acid)GSH reductase procedure. GSH was determined in a mixture containing $0.1 \mathrm{M}$ phosphate buffer ( $\mathrm{pH} 7.0$ ), $0.5 \mathrm{~m}$ Methylene diaminetetraacetic acid (EDTA) and 3mM 5,5dithio-bis-(2-nitrobenzoic acid) (DTNB). After $5 \mathrm{~min}$, absorbance for determination of GSH was read at $412 \mathrm{~nm}$ using UV-vis spectrophotometer. To the same tube, $0.4 \mathrm{mM}$ of NADPH and $2 \mu \mathrm{lGR}$ was added for the determination of total glutathione. The amount of GSSG was calculated by subtracting GSH from total glutathione concentrations and a standard curve was prepared from varying concentrations of reduced glutathione (Israr et al., 2006).

\subsection{Statistical analyses}

The parameters evaluated were submitted to normality test using the test Kolmogorov-Smirnov and Shapiro-Wilk, for the verification of absence of normality. A multiple comparison between means by the Tukey test followed by an individual ANOVA for each character at 0.05 level of significance were performed. The statistical analysis was performed using the Sisvar 5.3 software (Ferreira, 2011). 


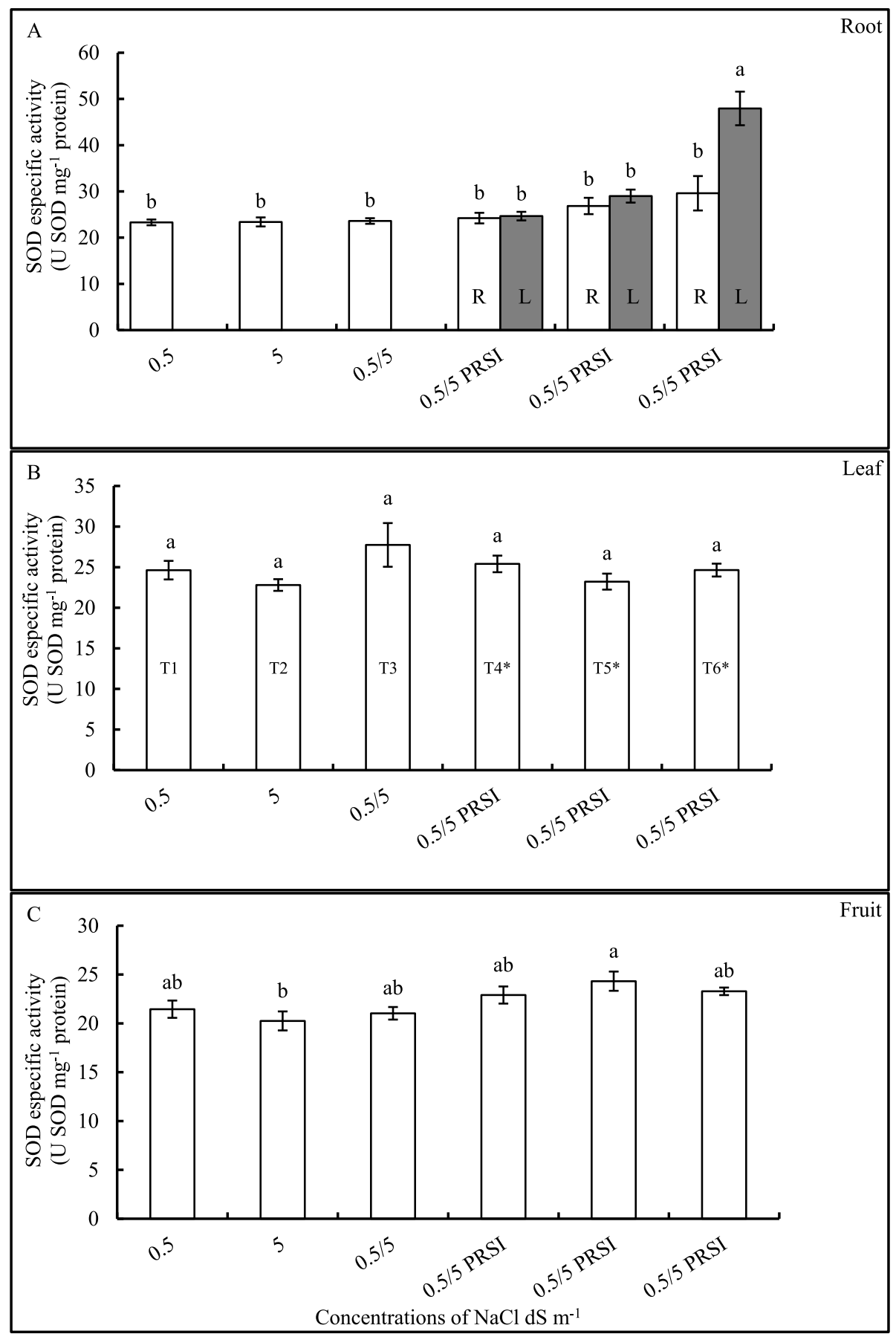

Fig. 6. SOD specific activity in roots (A), leaves (B) and fruits (C)(U SOD mg ${ }^{-1}$ protein) of tomato plants irrigated with saline water under PRSIwith significantly different at $\mathrm{P}<0.05$ by Tukey test, ${ }^{*} \mathrm{R}$ and $\mathrm{L}$ right and left sides of the root.

\section{Results}

\subsection{Plant growth and $\mathrm{Na}^{+}$content}

Roots of $\mathrm{T} 2, \mathrm{~T} 3$ and $\mathrm{T} 6 *$ treatments exhibited similar growth to control plants (T1), while roots of $\mathrm{T} 4 *$ and $\mathrm{T} 5 *$ treatments exhibited a reduction of dry mass compared to T1(Fig. 2A). Plants of T6* treatment exhibited an increase in leaf growth when compared with the leaves of T1, T2, T4* and T5* treatments (Fig. 2A). Treatments T2, T3, T4*, T5* and $\mathrm{T} 6 *$ showed similar fruit growth to the control T1, under the PRSI. T4* was superior to T6* (Fig. 2A). No changes were observed in total plant dry mass among all treatments (T2, T3, T4*, T5* and T6*) when compared to the control plants (Fig. 2B).
Roots of the $\mathrm{T}_{4} \mathrm{R}^{*}$ treatment exhibited lower $\mathrm{Na}^{+}$amount than $\mathrm{T} 2$ (high salinity) roots, while only roots of the plants $\mathrm{T} 5 \mathrm{~L}^{*}$ treatment exhibited higher $\mathrm{Na}^{+}$than control plants (Fig. 3A). Leaves of T2 treatment exhibited the highest $\mathrm{Na}^{+}$content among all treatments (Fig. 3B). The fruits that presented lower $\mathrm{Na}^{+}$treatments were $\mathrm{T} 1, \mathrm{~T} 4$ and $\mathrm{T} 6$ when compared to the T2 treatment (high salinity) (Fig. 3C). Total plant $\mathrm{Na}^{+}$content in plants of $\mathrm{T} 2, \mathrm{~T} 3$ and $\mathrm{T} 6$ * treatments exhibited higher $\mathrm{Na}^{+}$accumulation than control plants (T1) (Fig. 3D).

\subsection{Lipid peroxidation}

Lipid peroxidation, expressed as MDA content, was similar in roots of $\mathrm{T} 4 \mathrm{R}^{*}-\mathrm{T} 4 \mathrm{~L}^{*}$ and $\mathrm{T} 5 \mathrm{R}^{*}-\mathrm{T} 5 \mathrm{~L}^{*}$ treatments, which decreased lipid 


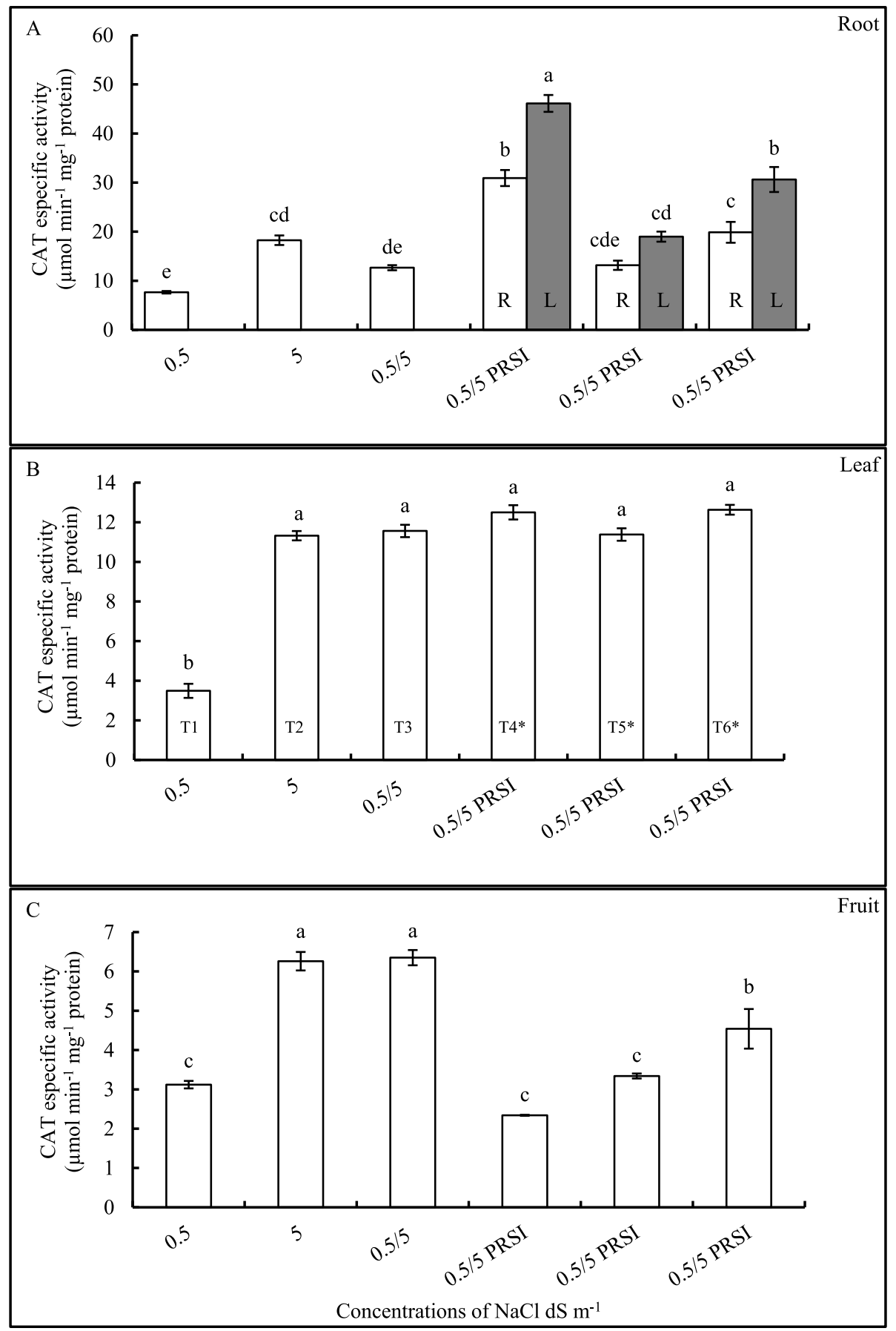

Fig. 7. CAT specific activity in roots (A), leaves (B) and fruits (C) ( $\mu \mathrm{mol} \mathrm{min}^{-1} \mathrm{mg}^{-1}$ protein) of tomato plants irrigated with saline water under PRSI with significantly different at $\mathrm{P}<0.05$ by Tukey test, *R and $\mathrm{L}$ represented right and left sides of the root.

peroxidation rates (Fig. 4A). The same pattern was observed among the leaves of treatments with PRSI (T4*, T5* and T6*) when compared to the control plants (T1) and treatments with high salinity (T2) (Fig. 4B). However, fruits of the plants T4* treatment showed low MDA content when compared to control plants (Fig. 4C).

\subsection{Proline content}

Proline content in roots of $\mathrm{T} 1, \mathrm{~T} 3, \mathrm{~T} 5 \mathrm{~L}^{*}$ and $\mathrm{T} 6 \mathrm{R}^{*}$-T6 $6 \mathrm{~L}^{*}$ treatments exhibited higher proline content compared to T2 (high salinity), T4R * -T4L * and T5R * presented lower content than T2 (Fig. 5A). The same effect was more pronounced in leaves of the plants T2 and T6 treatments, however T3 was also similar to T2 (Fig. 5B). Furthermore, only plants of $\mathrm{T} 4 *$ and $\mathrm{T} 5 *$ treatments showed low proline content when compared to control plants(Fig. 5C).

\subsection{Antioxidant enzymes activity}

CAT (Fig. 7), APX (Fig. 8) and GR (Fig. 9) activities are crucial for the detoxification of any excess $\mathrm{H}_{2} \mathrm{O}_{2}$ produced by SOD (Fig. 6) and/or by other metabolic processes. The overall results showed significant effects of SOD activity in fruits and roots (Fig. 6). In fruits (Fig. 6C), T2, $\mathrm{T} 3, \mathrm{~T} 4 *, \mathrm{~T}^{*}$ and $\mathrm{T} 6 *$ treatments showed similar SOD activity to the control plants. In roots, only $\mathrm{T} 6 \mathrm{~L}^{*}$ treatment showed high SOD activity compared to the other treatments (Fig. 6A).

In fruits, the CAT activity was more pronounced in plants of $\mathrm{T} 2$ and 


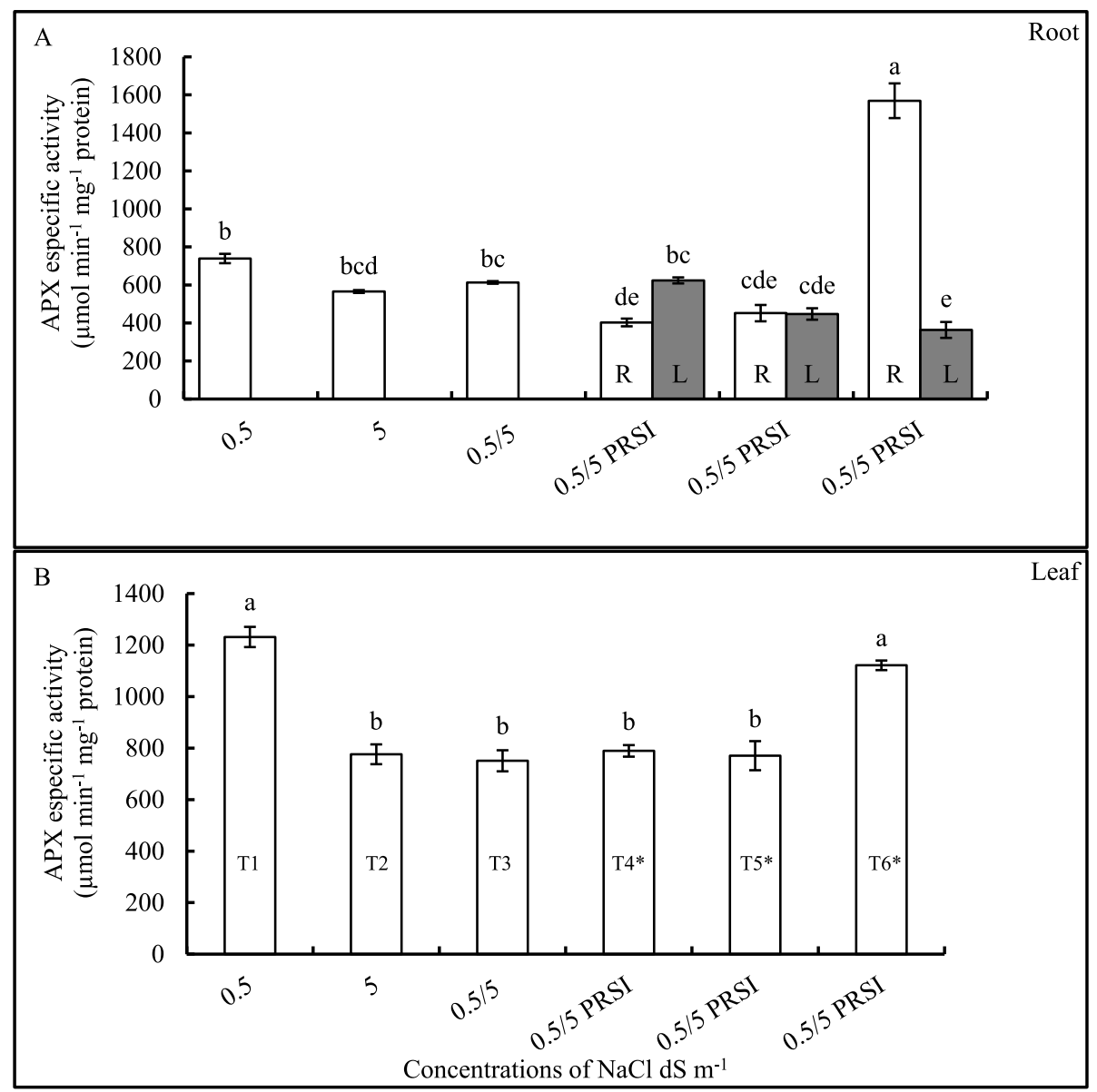

Fig. 8. APX specific activity in roots (A) and leaves (B) ( $\mu \mathrm{mol} \mathrm{min}^{-1} \mathrm{mg}^{-1}$ protein) of tomato plants irrigated with saline water under PRSI with significantly different at $\mathrm{P}<0.05$ by Tukey test, ${ }^{*} \mathrm{R}$ and $\mathrm{L}$ represented right and left sides of the root.

T3 treatments. However, fruits of plants submitted to PRSI system (T4* and $\mathrm{T}^{*}$ treatments) exhibited CAT activity similar to the control plants, with the exception of plants to T6* treatment (Fig. 7C). When the APX activity was analyzed in fruits no enzyme activity could be detected. In contrast, fruits of control plants showed higher GR activity when compared to plants with PRSI (T4*, T5* and T6*) treatments (Fig. 9C).

When roots were analyzed, plants of T4R* treatment exhibited the highest CAT activity compared to other treatments (Fig. 7A). Roots of T2, T4R*-T4L*, T5L* and T6R*-T6L* treatments showed higher CAT activity when compared to the control plants (Fig. 7A). Roots of T4R*, T5R*-T5L* and T6L* treatments with PRSI systems showed lower APX activity when compared to the control plants (Fig. 8A). However, roots of T4L* treatment exhibited the highest GR activity (Fig. 9A), while roots of T4R* treatment exhibited lower GR activity when compared to control plants T1, T2, T3, T5R* and T6R* treatment (Fig. 9A). Roots of T2, T3, T5R*-T5L* and T6R*-T6L* treatments showed GR activity similar to the control plants (Fig. 9A).

An interesting tendency was observed in enzymes activities among leaves of different treatments. Leaves of T2, T3, T4*, T5* and T6* treatments showed similar CAT activities, which were also higher than the control plants (Fig. 7B). The APX activity in leaves exhibited significant increase for both $\mathrm{T} 1$ and $\mathrm{T} 6$ *treatments compared to the other treatments(Fig. 8B), whereas the GR activity increased in leaves of T1, $\mathrm{T} 2$ and $\mathrm{T} 4 *$ treatments, however, T3, T5* and T6* treatments showed low GR activity. (Fig. 9B).

\subsection{GSH content}

The non-enzymatic GSH content did not show a response in roots. Leaves of T4* treatment showed the highest GSH content compared to all other treatments, in contrast to the observed results by leaves of T3 treatment, which showed the lowest GSH content among the treatments (Fig. 10A). In fruits, the highest GSH content occurred in fruits of T2 plants, while the lowest GSH was showed by fruits of $\mathrm{T} 1$ and $\mathrm{T} 4$ * treatments (Fig. 10B).

\section{Discussion}

The toxic effects of high soil salinity disrupt the development of plants. This deleterious response is often directly related to the length of exposure period, the salt's concentration, the specific crop tolerance and volume of transpired water by the plant (Hanin et al., 2016; Negrão et al., 2017; Rahnesan et al., 2018). Above all, the high salt concentration implicates in a lower soil water potential resulting in lower transpiration, lower photosynthesis rates and an imbalance in the mineral nutrient's uptake. As a result, there is an overproduction of ROS and increased oxidative damages (Farias et al., 2009; Liu et al., 2015; Yasar et al., 2016).

According to published data, there are evidence of positive effects in the growth rate and photosynthetic capacity in plants under the PRSI system (Koushafar et al., 2011; Dai et al., 2014; Guedes et al., 2015). Despite the deleterious effect of salinity to plant growth was not observed in all treatments (Fig. 2), the accumulation of $\mathrm{Na}^{+}$was higher in leaves and fruits (Fig. 3) of T2 treatment (high salinity) without the adoption of the PRSI system. 


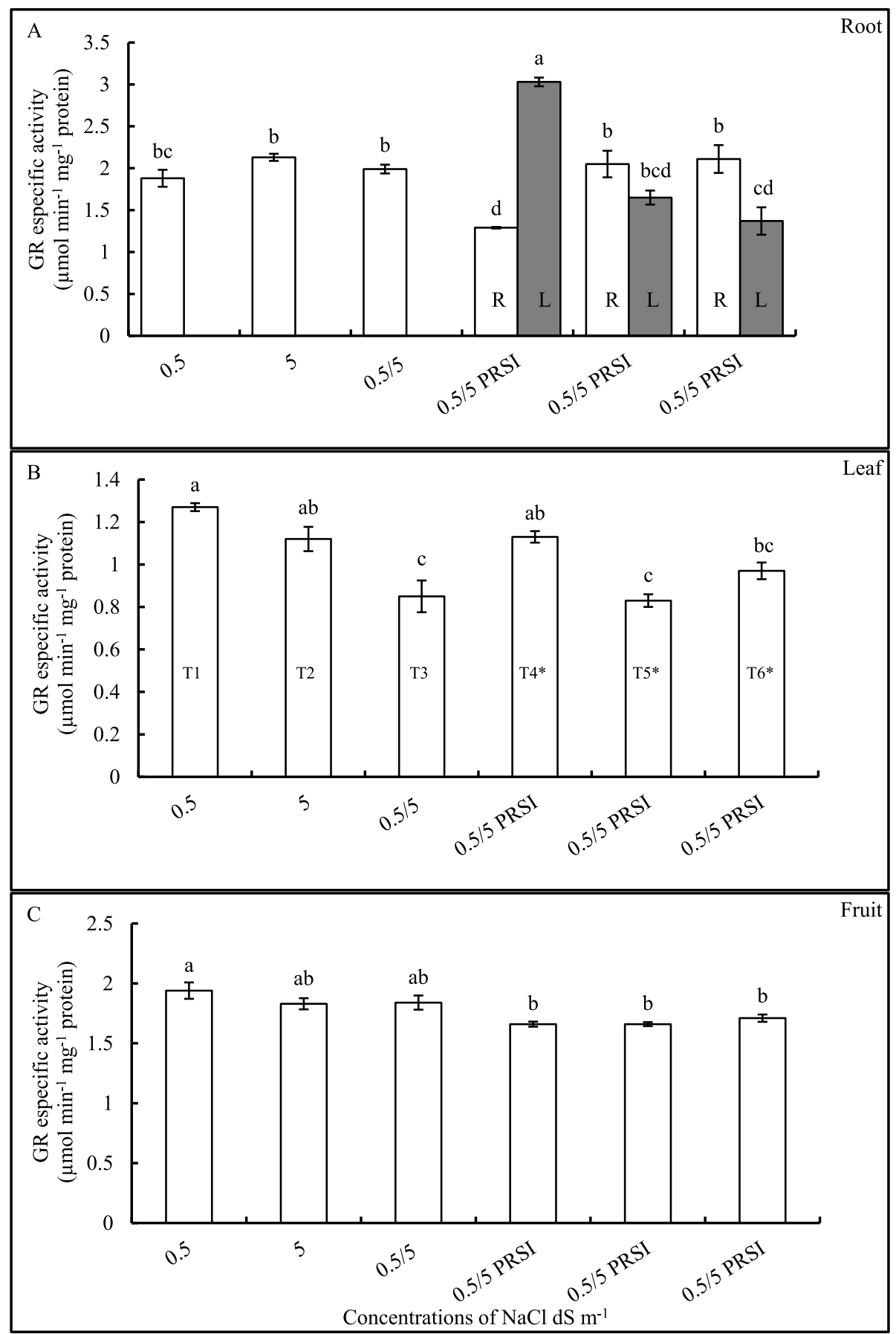

Fig. 9. GR specific activity in roots (A), leaves (B) and fruits (C) ( $\mu \mathrm{mol} \mathrm{min}^{-1} \mathrm{mg}^{-1}$ protein) of tomato plants irrigated with saline water under PRSI with significantly different at $\mathrm{P}<0.05$ by Tukey test, * $\mathrm{R}$ and $\mathrm{L}$ represented right and left sides of the root.

When plants are submitted to prolonged exposure to high salinity, the main site of $\mathrm{Na}^{+}$toxicity is in the limbo leaf, where photosynthesis and other metabolic processes occur, which can cause physiological damages in plants (Wang et al., 2015; Ma et al., 2016). Extrusion of $\mathrm{Na}^{+}$by plants into the substrate solution and removal of $\mathrm{Na}^{+}$from some tissues, especially in the xylem, can minimize deleterious effects of salinity on foliar metabolism, especially on the photosynthetic process (Munns, 2002). Our results are in agreement with results obtained by Kong et al. (2017), where the treatment with PRSI decreased the concentration of $\mathrm{Na}^{+}$in cotton plants.

High levels of $\mathrm{NaCl}$ can induce oxidative stress in plant cells and consequently increase ROS production (Alharby et al., 2016). These ROS are highly reactive and can induce the lipid peroxidation, causing damage to proteins, nucleic acids and also enzymes (Mishra et al., 2006; Duman and Koca, 2014).

According to the results (Fig. 4), the MDA content was higher in leaves among all treatments, however, the treatments adopting the PRSI showed similar MDA content in leaves compared to the control and T2 plants (higher salinity). However, in fruits, the MDA content under the T4* treatment was lower when compared to other treatments. This tendency is similar to the results observed in roots, where T4R*-T4L* and T5R*-T5L* treatments also demonstrated lower MDA content when compared to control. Therefore, through appropriate irrigation management the plants were relatively tolerant to salinity stress, due to the performance of CAT enzyme (Fig. 7). Furthermore, the increased MDA content on tissues submitted to salinity stress can be dependent on the 


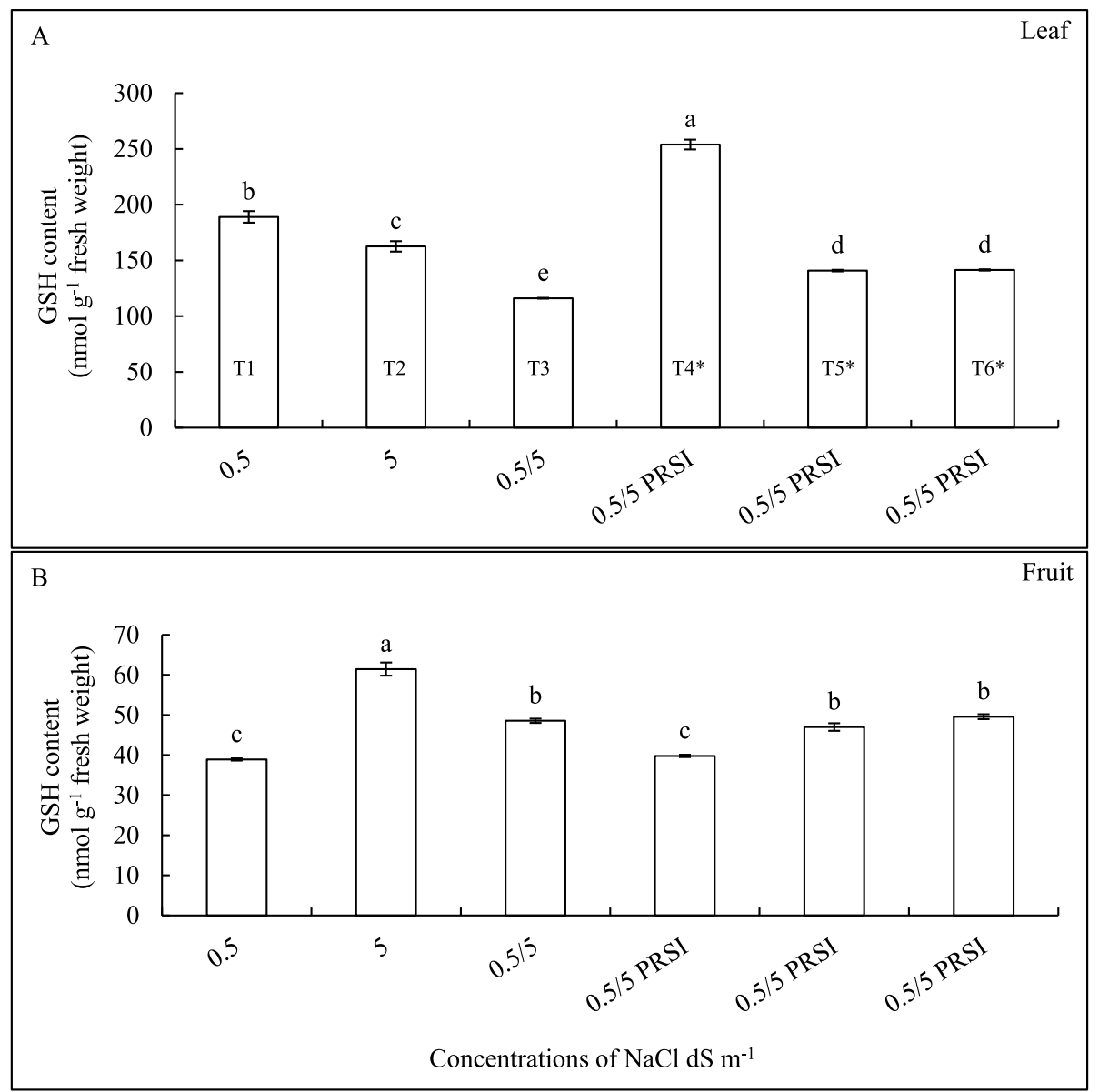

Fig. 10. GSH content in leaves (A) and fruits (B)(nmol g ${ }^{-1}$ fresh weight) of tomato plants irrigated with saline water under PRSI with significantly different at $\mathrm{P}<0.05$ by Tukey test.

non-regulation of the antioxidant defense system (Ediga et al., 2013). Leaves and roots of maize showed increased MDA content submitted to high salinity without water management systems (AbdElgawad et al., 2016).

Many plant species have shown a notable increase in Proline content as a direct response to salinity stress, which can contribute to the stabilization of protein molecules and membranes associated with the ROS scavenging within the cell (Bandeoglu et al., 2004; Bhusan et al., 2016). High proline content occurred in leaves of T2 and T6* treatments (Fig. 5), possibly as a direct response to the induced stress in order to protect the plant cells from the lipid peroxidation damage. Proline can act on cellular osmotic adjustment and detoxification of toxic ions in plants submitted to salinity stress (KaviKishor et al., 2005; Ashraf and Foolad, 2007).

The proline accumulation in fruits and roots showed to be lower than leaves, while plants of $\mathrm{T} 4 *$ and $\mathrm{T} 5 *$ treatments under PRSI, in these tissues, also had a lower Proline concentration compared to the control (Fig. 5). This was observed due to the management adopted in these treatments, where the plants were not $100 \%$ exposed to saline stress. This process caused the cell to maintain the normal metabolism, resulting in lower proline content, oppositional to the antioxidant enzymatic system against the lipid peroxidation.

Moreover, proline content did not change under high levels of salinity, such also observed in maize roots and leaves (AbdElgawad et al., 2016), in contrast to many reports where proline levels increased under salt stress to decrease the cellular water potential, and possibly scavenge ROS. By the other way, proline content increased in seven varieties of tomatoes submitted to high levels of salinity (Fariduddin et al., 2012). These findings have shown that salt stressful conditions depend on water management systems applied.

Antioxidant enzymes allow plants to avoid oxidative stress and survive to different environmental adversities (Gratão et al., 2015; Alves et al., 2017). SOD is one of the main antioxidant enzymes present in all aerobic organisms, which converts $\mathrm{O}_{2}{ }^{-}$into $\mathrm{H}_{2} \mathrm{O}_{2}$. It has been shown that SOD is induced in several plant species when exposed to high salinity (Zare and Pakniyat, 2012; Noctor and Foyer, 2016). In our work, SOD activity only increased in roots of $\mathrm{T} 6 \mathrm{~L}^{*}$ treatment in the roots (Fig. 6), possibly due to an excess of $\mathrm{NaCl}$ that has caused disorders or production of biomolecules, which may impair the metabolism of SOD (Mittler, 2002). A similar SOD activity pattern was observed in maize roots under salt stress adopting PRI system (Hu et al., 2010).

$\mathrm{H}_{2} \mathrm{O}_{2}$ produced in response to SOD activity or other metabolic activities can be reduced to $\mathrm{H}_{2} \mathrm{O}$ and $\mathrm{O}_{2}$ by the action of CAT, APX and others peroxidases (Carneiro et al., 2011; Liu et al., 2015). According to our results for SOD activity, it can be demonstrated that the generation of $\mathrm{H}_{2} \mathrm{O}_{2}$ occurred from other metabolic processes, activating other enzymes of the antioxidant defense system (Liu et al., 2015).

When other antioxidant enzymes are concerned, CAT and APX (Fig. 7) are involved in $\mathrm{H}_{2} \mathrm{O}_{2}$ degradation, whereas GR (Fig. 7) did not apparently participate effectively in such process. CAT activity was higher in all treatments, excepting fruits of $\mathrm{T} 4 *$ and $\mathrm{T} 5 *$ treatments and roots of T3 and T5D* treatments (Fig. 7). CAT has been considered an important enzyme in the direct breakdown of $\mathrm{H}_{2} \mathrm{O}_{2}$ (Carneiro et al., 2011; Mittler et al., 2011; Srinieng et al., 2015), acting to prevent oxidative damages from salinity stress independent of the treatment adopted.

Even though the CAT activity increased in tomato plants under salt 
stress (Mittova et al., 2003, 2004; Fariduddin et al., 2012), we demonstrated the stability of CAT activity in tomato root, leaf and fruit adopting PRSI systems which indicates that levels CAT levels can affect photorespiratory pathway in response to salt stress (Acosta-Motos et al., 2017), since that increased CAT activity can reduce the photorespiratory $\mathrm{CO}_{2}$ loss (Brisson et al., 1998).

Differently from CAT activity, APX exhibited high activity in leaves of T1 and T6* treatments (Fig. 8). In contrast to observed by CAT activity, plants of T2, T3, T4* and T5* treatments, did not exhibit changes in APX activity. In roots, the highest APX activity was showed in T6R* treatment, which can be related to the decrease in CAT activity. There was not a considerable increase in observed APX activity in most treatments (Fig. 8), which could also be explained by the higher CAT activity, low production of $\mathrm{H}_{2} \mathrm{O}_{2}$, and different APX location, such as chloroplasts, apoplasts, mitochondria and cytosol (Mittler, 2002; Dogan, 2012). According to Mittler (2002) and Locato et al. (2010), APX participates in the ascorbate-glutathione cycle in chloroplasts and mitochondria. In this cycle, the formed $\mathrm{H}_{2} \mathrm{O}_{2}$ from SOD is reduced by the ascorbate, which could also explain the low APX activity, considering that there was no difference in most of the treatments for SOD in tissues analyzed.

The enzyme GR plays an important role in maintaining the metabolic balance between $\mathrm{GSH}$, ascorbate (AsA) contents and $\mathrm{H}_{2} \mathrm{O}_{2}$ degradation (Alves et al., 2017). GR is therefore a key enzyme that provides plant protection against a series of abiotic stresses (RomeroPuertas et al., 2006; Sharma et al., 2012; Noctor et al., 2012). Based on the results observed, it appears that high GR activity occurred in roots, followed by fruits and leaves (Fig. 9). However, plants exposed to high salinity (T2) exhibited similar GR activities when compared to control plants. In addition, the fruits in PRSI treatments exhibited lower GR activities when compared to control plants. By the other way, increased GR activity was demonstrated in tomato plants adopting saline water management systems (Manai et al., 2014)

This result shows damage to the enzymatic system due to stress, such as others studies have shown (Chattopadhayay et al., 2002; Dogan et al., 2010a,b; Dogan, 2012; Mohamed et al., 2015), indicating that saline stress can affect GR levels differently, where these responses may be related to other mechanisms still unknown (Dogan, 2012; Mohamed et al., 2015).

Contrarily, the GSH is a non-enzymatic antioxidant compound that protects plant cells from oxidative damage by scavenging ROS, regeneration and degradation of enzymes such as GR and glutathione peroxidase (GPX) (Guo et al., 2016). Studies have shown that the antioxidant efficiency of this compound can be reduced when plants are exposed to salinity stress for long periods (Bernstein et al., 2010; Arghavani et al., 2012). GSH regeneration occurs from reduced glutathione (GSSG) which is catalyzed by glutathione reductase (GR), using NADPH as a reducing agent (Gratão et al., 2012; Nogueirol et al., 2015). Thus, overall results obtained for GSH content (Fig. 10) showed the strict relation between GSH and GR, however not in roots, where the GSH content could not be quantified due to the lower GR levels in this tissue with the exception of T4L*. Another explanation may also be given by the low activity of APX in the present work, since it can use ascorbic acid (AA) as a substrate, which is oxidized to dehydroascorbate (DHA), resulting in AA accumulation, which could maintain levels of DHA in turn. DHA is then regenerated through the enzyme dehydroascorbate reductase (DHAR, EC1.8.5.1), which oxidizes GSH to GSSG. Therefore, due to the low levels of DHA, GSH could not have been used against oxidative damages (Gratão et al., 2008) except in T2 (fruits) and T4 * (leaves) that had increased GSH (Fig. 10). Other findings with saline water managements systems add further support to reduce damage effects of stress in tomato plants (Mohamed et al., 2015, Li et al., 2015), since that low GSH content was observed with the use of saline water without management strategy.

The defense systems are an integral part of plant metabolism that allows plants to cope instantly with environmental changes, once the tolerance to salinity stress can be associated with increased enzymatic activities and non-enzymatic compounds (Tari et al., 2015).

According to results, T4, T5 and T6 water managements adopted with PRSI system could be used such management strategies since tomato plants did not show to be vulnerable to salt stress when using this system, supported by antioxidant responses. However, overall results demonstrated that $\mathrm{T} 4$ and $\mathrm{T} 5$ water managements were more efficient in response to salt stressful-conditions than T6 water management. The low efficiency of T6 treatment may be related to the water management adopted, whereas the interchange between low and high saline water can increase salt content in both sides of the root-zone. A high salt content can cause ionic toxicity and, consequently to cause an imbalance between the production and scavenging of ROS in plants, leading to oxidative stress (Chawla et al., 2013; AbdElgawad et al., 2016; Wang et al., 2018). The results obtained in the present work demonstrated that the viability of PRSI system appears to be dependent on the salinity level and time exposure of roots to the salts of nutrient solution and saline water.

It is noteworthy that studies with the PRI system using saline water are scarce, in particular, about the antioxidant defense systems (Koushafar et al., 2011; Guedes et al., 2015). Therefore, our study presents an innovative follow-up when compared to the current literature, in view of physiological and biochemical approaches.

\section{Conclusion}

The overall results showed that PRSI system could be an applicable technique for saline water supply on irrigation, since tomato plants did not show to be vulnerable to salt stress when using this system, supported by a biochemical approach involving antioxidant responses.

\section{Acknowledgments}

We thank Conselho Nacional de Desenvolvimento Científico e Tecnológico (CNPq - Grant n. 445978/2014-7) and Coordenação de Aperfeiçoamento de Pessoal de Nível Superior for the scholarship granted.

\section{References}

AbdElgawad, H., Zinta, G., Hegab, M.M., Renu Pandey, R., Asard, H., Abuelsoud, W., 2016. High salinity induces different oxidative stress and antioxidant responses in maize seedlings organs. Front. Plant Sci. 7, 1-11. http://dx.doi.org/10.3389/fpls. 2016.00276.

Abreu, I.A., Farinha, A.P., Negrão, S., Gonçalves, N., Fonseca, C., Rodrigues, M., Batista, R., Saíbo, N.J.M., Oliveira, M.M., 2013. Coping with abiotic stress: proteome changes for crop improvement. Journal of Proteomics 93, 145-168. http://dx.doi.org/10. 1016/j.jprot.2013.07.014.

Acosta-Motos, J.R., Ortuño, M.F., Bernal-Vicente, A., Diaz-Vivancos, P., Sanchez-Blanco, M.J., Hernandez, J.A., 2017. Review: plant responses to salt stress: adaptive mechanisms. Agronomy 7, 1-38. http://dx.doi.org/10.3390/agronomy7010018.

Ahmad, P., Jaleel, C.A., Sharma, S., 2010. Antioxidant defense system, lipid peroxidation, proline-metabolizing enzymes, and biochemical activities in two Morusalba genotypes subjected to NaCl stress. Russ. J. Plant Physiol. 57, 509-517. http://dx.doi.org/ 10.1134/S1021443710040084.

Alharby, H.F., Metwali, E.M., Fuller, M.P., Aldhebiani, A.Y., 2016. Impact of application of zinc oxide nanoparticles on callus induction, plant regeneration, element content and antioxidant enzyme activity in tomato (Solanum lycopersicum Mill.) under salt stress. Arch. Biol. Sci. 00http://dx.doi.org/10.2298/ABS151105017A. 17-17.

Alves, L.R., Monteiro, C.C., Carvalho, R.F., Ribeiro, P.C., Tezotto, T., Azevedo, R.A., Gratão, P.L., 2017. Cadmium stress related to root-to-shoot communication depends on ethylene and auxin in tomato plants. Environ. Exp. Bot. 134, 102-115. http://dx. doi.org/10.1016/j.envexpbot.2016.11.008.

Arghavani, M., Kafi, M., Babalar, M., Naderi, R., Hoque, M.A., Murata, Y., 2012. Improvement of salt tolerance in Kentucky bluegrass by trinexapac-ethyl. Hortscience 47, 1163-1170.

Ashraf, M., Foolad, M.R., 2007. Improving plant abiotic-stress resistance by exogenous application of osmoprotectants glycine betaine and proline. Environ. Exp. Bot. 59, 206-216. http://dx.doi.org/10.1016/j.envexpbot.2016.11.008.

Bandeoglu, E., Eyidogan, F., Yucel, M., Avni, Oktem, H., 2004. Antioxidant responses of shoots and roots of lentil to NaCl-salinity stress. Plant Growth Regul. 42, 69-77. http://dx.doi.org/10.1023/B: GROW.0000014891.35427.7b.

Bazihizina, N., Barrett-Lennard, E.G., Colmer, T.D., 2012. Plant growth and physiology 
under heterogeneous salinity. Plant Soil 354, 1-19. http://dx.doi.org/10.1007/ s11104-012-1193-8.

Bernstein, N., Shoresh, M., Xu, Y., Huang, B., 2010. Involvement of the plant antioxidative response in the differential growth sensitivity to salinity of leaves vs roots during cell development. Free Radical Biol. Med. 49, 1161-1171. http://dx.doi.org/ 10.1016/j.freeradbiomed.2010.06.032.

Bhusan, D., Das, D.K., Hossain, M., Murata, Y., Hoque, M.A., 2016. Improvement of salt tolerance in rice (Oryza sativa L.) by increasing antioxidant defense systems using exogenous application of proline. Aust. J. Crop. Sci. 10, 50.

Boaretto, L.F., Carvalho, G., Borgo, L., Creste, S., Landell, M.G.A., Mazzafera, P., Azevedo, R.A., 2014. Water stress reveals differential antioxidant responses of tolerant and non-tolerant sugarcane genotypes. Plant Physiol. Biochem. 74, 165-175. http://dx. doi.org/10.1016/j.plaphy.2013.11.016.

Borghesi, E., González-Miret, M.L., Escudero-Gilete, M.L., Malorgio, F., Heredia, F.J., Meléndez-Martínez, A.J., 2011. Effects of salinity stress on carotenoids, anthocyanins, and color of diverse tomato genotypes. J. Agric. Food Chem. 59, 11676-11682. http://dx.doi.org/10.1021/jf2021623.

Bradford, M.M., 1976. Rapid and sensitive method for the quantitation of microgram quantities of protein utilizing the principle of protein-dye binding. Anal. Biochem. 71, 248-254. http://dx.doi.org/10.1016/0003-2697(76)90527-3.

Brisson, L.F., Zelitch, I., Havir, E.A., 1998. Manipulation of catalase levels produces altered photosynthesis in transgenic tobacco plants. Plant Physiol. 116, 259-269.

Carneiro, M.M.L.C., Deuner, S., Oliveira, P.D., Teixeira, S.B., Sousa, C.P., Bacarin, M.A. Moraes, D.D., 2011. Atividade antioxidante e viabilidade de sementes de girassol após estresse hídrico e salino. Rev. Bras. Sementes 33, 752-761.

Carvalho, R.F., Monteiro, C.C., Caetano, A.C., Dourado, M.N., Gratão, P.L., Haddad, C.K.B., Peres, L.E.P., Azevedo, R.A., 2013. Leaf senescense in tomato mutants as affected by irradiance and phytohormones. Biol. Plant. (Prague) 57, 749-757. http:// dx.doi.org/10.1007/s10535-013-0333-1.

Chattopadhayay, M.K., Tiwari, B.S., Chattopadhyay, G., Bose, A., Sengupta, D.N., Ghosh, B., 2002. Protective role of exogenous polyamines on salinity-stressed rice (Oryza sativa) plants. Physiol. Plantarum 116, 192-199. http://dx.doi.org/10.1034/j.13993054.2002.1160208.x.

Chawla, S., Jain, S., Jain, V., 2013. Salinity induced oxidative stress and antioxidant system in salt-tolerant and salt-sensitive cultivars of rice (Oryza sativa L.). J. Plant Biochem. Biotechnol. 22, 27-34. http://dx.doi.org/10.1007/s00709-011-0365-3.

Cia, M.C., Guimarães, A.C.R., Medici, L.O., Chabregas, S.M., Azevedo, R.A., 2012. Antioxidant response to water deficit by drought-tolerant and -sensitive sugarcane varieties. Ann. Appl. Biol. 161, 313-324.

Cuypers, A., Plusquin, M., Remans, T., Jozefczak, M., Keunen, E., Gielen, H., Opdenakker, K., Nair, A.R., Munters, E., Artois, T.J., Nawrot, T., Vangronsveld, J., Smeets, K., 2010. Cadmium stress: an oxidative challenge. Biometals 23, 927-940. http://dx.doi. org/10.1007/s10534-010-9329-x.

Dai, J.L., Duan, L.S., Dong, H., 2014. Improved nutrient uptake enhances cotton growth and. Z. salinity tolerance in saline media. J. Plant Nutr. 37, 1269-1286. http://dx. doi.org/10.1080/01904167.2014.881869.

Deinlein, U., Stephan, A.B., Horie, T., Luo, W., Xu, G., Schroeder, J.I., 2014. Plant salttolerance mechanisms. Trends Plant Sci. 19, 371-379. http://dx.doi.org/10.1016/j. tplants.2014.02.001.

Dogan, M., 2012. Investigation of the effect of salt stress on the antioxidant enzyme activities on the young and old leaves of salsola (Stenoptera) and tomato (Lycopersicon esculentum L.). Afr. J. Plant Sci. 6, 62-72. http://dx.doi.org/10.5897/AJPS11.116.

Dogan, M., Tipirdamaz, R., Demir, Y., 2010a. Effective salt criteria in callus-cultured tomato genotypes. J. Biosci. 65, 613-618. http://dx.doi.org/10.1515/znc-2010-91014.

Dogan, M., Tipirdamaz, R., Demir, Y., 2010b. Salt resistance of tomato species grown in sand culture. Plant Soil Environ. 56, 499-507.

Duman, F., Koca, F.D., 2014. Single and combined effects of exposure concentration and duration on biological responses of Ceratophyllum demersum L. Exposed to $\mathrm{Cr}$ species. Int. J. Phytoremediation 16, 1192-1208. http://dx.doi.org/10.1080/15226514. 2013.821450 .

Ediga, A., Hemalatha, S., Meriga, B., 2013. Effect of salinity stress on antioxidant defense system of two finger millet cultivars (Eleusine coracana (L.) gaertn) differing in their sensitivity. Adv. Biol. Res. 7, 180-187. http://dx.doi.org/10.5829/idosi.abr.2013.7. 5.1113.

Epstein, E., Bloon, A.J., 2005. Mineral nutrition of Plants Principles and Perspectives, 2 ed. Oxford University Press, Sunderland (Massachusetts), pp. 400.

Farias, S.G.G., Santos, D.R.D., Freire, A.L.D.O., Silva, R.B., 2009. Estresse salino no crescimento inicial e nutrição mineral de Gliricídia (Gliricidia sepium (Jacq.) KuntexSteud) em solução nutritiva. Rev. Bras. Ciência do Solo 33, 1499-1505. http://dx.doi.org/10.1590/S0100-06832009000500040.

Fariduddin, Q., Mir, B.A., Ahmad, A., 2012. Physiological and biochemical traits as tools to screen sensitive and resistant varieties of tomatoes exposed to salt stress. Braz. J. Plant Physiol. 24, 281-292. http://dx.doi.org/10.1590/S1677-04202012000400001.

Ferreira, D.F., 2011. Sisvar: a computer statistical analysis system. Cienc. E Agrotecnol 35, 1039-1042. http://dx.doi.org/10.1590/S1413-70542011000600001.

Foyer, C.H., Noctor, G., 2013. Redox signaling in plants. Antioxidants Redox Signal. 18, 2087-2090. http://dx.doi.org/10.1089/ars.2013.5278.

Gratão, P.L., Polle, A., Lea, P.J., Azevedo, R.A., 2005. Making the life of heavy metal stressed plants a little easier. Funct. Plant Biol. 32, 481-494. http://dx.doi.org/10. 1071/FP05016.

Gratão, P.L., Pompeu, G.B., Capaldi, F.R., Vitorello, V.A., Lea, P.J., Azevedo, R.A., 2008. Antioxidant response of Nicotiana tabacum cv. Bright Yellow 2 cells to cadmium and nickel stress. Plant Cell. Tissue and Organ Culture 94, 73-83. http://dx.doi.org/10. 1007/s11240-008-9389-6.

Gratão, P.L., Monteiro, C.C., Carvalho, R.F., Tezotto, T., Piotto, F.A., Peres, L.E.P.,
Azevedo, R.A., 2012. Biochemical dissection of diageotropica and Never ripe tomato mutants to Cd stressful conditions. Plant Physiol. Biochem. 56, 79-96. http://dx.doi. org/10.1016/j.plaphy.2012.04.009.

Gratão, P.L., Monteiro, C.C., Tezotto, T., Carvalho, R.F., Alves, L.R., Peters, L.J., Azevedo, R.A., 2015. Cadmium stress antioxidant responses and root-to-shoot communication in grafted tomato plants. Biometals 28, 803-816. http://dx.doi.org/10.1007/s10534015-9867-3.

Guedes, R.A., De Oliveira, F.D.A., Alves, R.C., De Medeiros, A.S., Gomes, L.P., Costa, L.P., 2015. Estratégias de Irrigação com Água salina não tomateiro cereja em ambiente protegido. Rev. Bras. Eng. Agrícola Ambient. 19, 913-919. http://dx.doi.org/10. 1590/1807-1929/agriambi.v19n10p913-919.

Guo, B., Liu, C., Li, H., Yi, K., Ding, N., Li, N., Fu, Q., 2016. Endogenous salicylic acid is required for promoting cadmium tolerance of Arabidopsis by modulating glutathione metabolisms. J. Hazard Mater. 316, 77-86. http://dx.doi.org/10.1016/j.jhazmat. 2016.05.032.

Hanin, M., Ebel, C., Ngom, M., Laplaze, L., Masmoudi, K., 2016. New insights on plant salt tolerance mechanisms and their potential use for breeding. Front. Plant Sci. 7, 1-17. http://dx.doi.org/10.3389/fpls.2016.01787.

Henareh, M., Hassani, G., 2014. Effects of transplanting stage of seedling and planting depth on growth and yield of tomato cv. Petoearly ch. Seed and Plant Production Journal 30, 103-113.

Hu, T., Yuan, L., Wang, J., Kang, S., Li, F., 2010. Antioxidation responses of maize roots and leaves to partial root-zone irrigation. Agric. Water Manag. 98, 164-171. http:// dx.doi.org/10.1016/j.agwat.2010.06.019.

Ismail, D.A., Takeda, S., Nick, P., 2014. Review Life and death under salt stress: same players, different timing? J. Exp. Bot. 159, 17. http://dx.doi.org/10.1093/jxb/ eru159.

Israr, M., Sahi, S., Datta, R., Sarkar, D., 2006. Bioaccumulation and physiological effects of mercury in Sesbaniadrummondii. Chemosphere 65, 591-598. http://dx.doi.org/ 10.1016/j.chemosphere.2006.02.016.

Kang, S., Zhang, J., 2004. Controlled alternate partial root-zone irrigation: its physiological consequences and impact on water use efficiency. J. Exp. Bot. 55, 2437-2446. http://dx.doi.org/10.1093/jxb/eru159.

KaviKishor, P.B., Sangam, S., Amrutha, R.N., Laxmi, P.S., Naidu, K.R., Rao, K.R.S.S., Rao, S., Reddy, K.J., Theriappan, P., Sreenivasulu, N., 2005. Regulation of proline biosynthesis, degradation, uptake and transport in higher plants: its implications in plant growth and abiotic stress tolerance. Curr. Sci. 88, 424-438.

Kong, X., Luo, Z., Dong, H., Li, W., Chen, Y., 2017. Non-uniform salinity in the root zone alleviates salt damage by increasing sodium, water and nutrient transport genes expression in cotton. Sci. Rep. 7, 1-13. http://dx.doi.org/10.1038/s41598-01703302-x.

Koushafar, M., Khoshgoftarmanesh, A.H., Moezzi, A., Mobli, M., 2011. Effect of dynamic unequal distribution of salts in the root environment on performance and Crop Per Drop (CPD) of hydroponic-grown tomato. Sci. Hortic. 131, 1-5. http://dx.doi.org/10. 1016/j.scienta.2011.09.016.

Kusakabe, A., Melgar, J.C., Dunlop, J., Syvertsen, J.P., 2009. Partial root zone drying with and without salinity affects water use effi ciency of citrus. Florida State Horticultural Society 122, 60-62.

Li, J., Hu, L., Zhang, L., Pan, X., Hu, X., 2015. Exogenous spermidine is increasing tomato tolerance to salinity-alkalinity stress by regulating the chloroplast antioxidant system and chlorophyll metabolism. BMC Plant Biol. 15, 1-17. http://dx.doi.org/10.1186/ s12870-015-0699-7.

Liu, F., Savic, S., Jensen, C.R., Shahnazari, A., Jacobsen, S.E., Stikic, R., Anderson, M.N., 2007. Water relations and yield of lysimeter-grow strawberries under limited irrigation. Sci. Hortic. 111, 128-132. http://dx.doi.org/10.1016/j.scienta.2011.09.016.

Liu, S.L., Yang, R.J., Ma, M.D., Dan, F., Zhao, Y., Jiang, P., Wang, M.H., 2015. Effects of exogenous NO on the growth, mineral nutrient content, antioxidant system, and ATPase activities of Trifoliumrepens L. plants under cadmium stress. Acta Physiol. Plant. 37, 1-16. http://dx.doi.org/10.1007/s11738-014-1721-7.

Locato, V., de Pinto, M.C., Paradiso, A., De Gara, L., 2010. Reactive oxygen species and ascorbate-glutathione interplay in signaling and stress responses. Reactive Oxygen Species and Antioxidants in Higher Plants 45. http://dx.doi.org/10.1201/ 9781439854082-4.

Ma, X., Zhang, J., Huang, B., 2016. Cytokinin-mitigation of salt-induced leaf senescence in perennial ryegrass involving the activation of antioxidant systems and ionic balance. Environ. Exp. Bot. 125, 1-11. http://dx.doi.org/10.1016/j.envexpbot.2016.01. 002.

Manai, J., Kalai, T., Gouia, H., Corpas, F.J., 2014. Exogenous nitric oxide (NO) ameliorates salinity-induced oxidative stress in tomato (Solanum lycopersicum) plants. J. Soil Sci. Plant Nutr. 14, 433-446. http://dx.doi.org/10.4067/S071895162014005000034.

Maskri, A., Al-Kharusi, L., Al-Miqbali, H., 2010. Effects of salinity stress on growth of lettuce (Lactuca sativa) under closed-recycle nutrient film technique. Int. J. Agric Biol. 12, 377-380.

Miranda, F.R., Mesquita, A.L.M., Martins, M.V.V., Fernandes, C.M.F., Evangelista, M.I.P., Sousa, A.A.P., 2011. Produção de tomate em substrato de fibra de coco. Fortaleza, Embrapa Agroindústria Tropical, pp. 20 (Circular Técnica, 33).

Mishra, S., Srivastava, S., Tripathi, R.D., Govindarajan, R., Kuriakose, S.V., Prasad, M.N.V., 2006. Phytochelatin synthesis and response of antioxidants during cadmium stress in Bacopamonniera. Plant Physiol. Biochem. 44, 25-37. http://dx.doi.org/10. 1016/j.plaphy.2006.01.007.

Mittler, R., 2002. Oxidative stress, antioxidants and stress tolerance. Trends Plant Sci. 7, 405-410. http://dx.doi.org/10.1016/S1360-1385(02)02312-9.

Mittler, R., Vanderauwera, S., Suzuki, N., Miller, G., Tognetti, V.B., Vandepoele, K., Gollery, M., Shulaev, V., Van Breusegem, F., 2011. ROS signaling: the new wave? Trends Plant Sci. 16, 300-309. http://dx.doi.org/10.1016/S1360-1385(02)02312-9. 
Mittova, V., Tal, M., Volokita, M., Guy, M., 2003. Up-regulation of the leaf mitochondrial and peroxisomal antioxidative systems in response to salt-induced oxidative stress in the wild salt-tolerant tomato species Lycopersicon pennellii. Plant Cell Environ. 26, 845-856.

Mittova, V., Guy, M., Tal, M., Volokita, M., 2004. Salinity up-regulates the antioxidative system in root mitocondria and peroxisomes of the wild salt-tolerant tomato species Lycopersicon pennellii. Jornal of Experimental Botany 399, 1105-1113. http://dx. doi.org/10.1093/jxb/eru159.

Mohamed, H.E., Hemeida, A.E., Mohamed, A.G., 2015. Role of hydrogen peroxide pretreatment on developing antioxidant capacity in the leaves of tomato plant (lycopersicon Esculentum) grown under saline stress. Int. J. Adv. Res. 3, 878-879.

Munns, R., 2002. Comparative physiology of salt and water stress. Plant. Cell \& Environment 25, 239-250. http://dx.doi.org/10.1046/j.0016-8025.2001.00808.x.

Murshed, R., Lopez-Lauri, F., Sallanon, H., 2014. Effect of salt stress on tomato fruit antioxidant systems depends on fruit development stage. Physiol. Mol. Biol. Plants 20, 15-29. http://dx.doi.org/10.1007/s12298-013-0209-z.

Nawaz, F., Ashraf, M.Y., Ahmad, R., Waraich, E.A., Shabbir, R.N., Bukhari, M.A., 2015 Supplemental selenium improves wheat grain yield and quality through alterations in biochemical processes under normal and water deficit conditions. Food Chem. 175, 350-357. http://dx.doi.org/10.1016/j.foodchem.2014.11.147.

Negrão, S., Schmöckel, S.M., Tester, M., 2017. Evaluating physiological responses of plants to salinity stress. Ann. Bot. 119, 1-11. http://dx.doi.org/10.1093/aob/ mcw191.

Noctor, G., Foyer, C.H., 2016. Intracellular Redox Compartmentation and ROS-related communication in regulation and signaling. Plant Physiol. 171, 1581-1592. http:// dx.doi.org/10.1104/pp.16.00346.

Noctor, G., Mhamdi, A., Chaouch, S., Han, Y.I., Neukermans, J., MarquezGarcia, B.E.L.E.N., Foyer, C.H., 2012. Glutathione in plants: an integrated overview. Plant Cell Environ. 35, 454-484. http://dx.doi.org/10.1046/j.0016-8025.2001.00808.x.

Nogueirol, R.C., Monteiro, F.A., Gratão, P.L., Borgo, L., Azevedo, R.A., 2015. Tropical soils with high aluminum concentrations cause oxidative stress in two tomato genotypes. Environ. Monit. Assess. 187, 1-16. http://dx.doi.org/10.1007/s10661-0154282-3.

Parvin, K., Ahamed, K.U., Islam, M.M., Haque, M.D.N., 2015. Response of tomato plant under salt stress: role of exogenous calcium. J. Plant Sci. 10, 222-233. http://dx.doi. org/10.3923/jps.2015.222.233.

Pompeu, G.B., Vilhena, M.B., Gratão, P.L., Carvalho, R.F., Rossi, M.L., Martinelli, A.P., Azevedo, R.A., 2016. Abscisic acid-deficient sit tomato mutant responses to cadmium-induced stress. Protoplasma 1-13. http://dx.doi.org/10.1007/s00709-0160989-4.

Rahnesan, Z., Nasibi, F., Moghadan, A.A., 2018. Effects of salinity stress on some growth, physiological, biochemical parameters and nutrients in two pistachio (Pistacia vera L.) rootstocks. J. Plant Interact. 13, 73-82. http://dx.doi.org/10.1080/17429145. 2018.1424355.

Richards, L.A., 1954. Diagnosis and Improvement of Saline and Alkali Soils. United States Salinity Laboratory, Washington, pp. 160 USDA, Agriculture Handbook, 60.

Romero-Puertas, M.C., Corpas, F.J., Sandalio, L.M., Leterrier, M., Rodriguez-Serrano, M., Del Rio, L.A., Palma, J.M., 2006. Glutathione reductase from pea leaves: response to abiotic stress and characterization of the peroxisomalisozyme. New Phytol. 170, 43-52. http://dx.doi.org/10.1111/j.1469-8137.2006.01643.x.

Serkedjieva, J., 2011. Antioxidant effects of plant polyphenols: a case study of a polyphenol-rich extract from Geranium sanguineum L. In: In: GUPTA, S.D. (Ed.), Reactive Oxygen Species and Antioxidants in Higher Plants, vol. 13. Enfield: Science
Publishers, pp. 275-293.

Shahnazari, A., Liu, F., Andersen, M.N., Jacobson, S.E., Jensen, C.R., 2007. Effects of partial root-zone drying on yield, tuber size and water use efficiency in potato under field conditions. Field Crop. Res. 100, 117-124. http://dx.doi.org/10.1016/j.fcr 2012.09.009.

Sharma, P., Jha, A.B., Dubey, R.S., Pessarakli, M., 2012. Reactive oxygen species, oxidative damage, and antioxidative defense mechanism in plants under stressful conditions. Journal of Botany 2012, 1-26. http://dx.doi.org/10.1155/2012/217037.

Shimizu, N., Hosogi, Park, P.J., 2006. Reactive oxygen species (ROS) generation and ROSinduced lipid peroxidation are associated with plasma membrane modifications in host cells in response to AK-toxin I from Alternaria alternate Japonese pear pathotype. J. Gen. Plant Pathol. 72, 6-15. http://dx.doi.org/10.1007/s10327-005-0245-9.

Souza, L.A., Piotto, F.A., Nogueirol, R.C., Azevedo, R.A., 2013. Use of non-hyperaccumulator plant species for the phytoextraction of heavy metals using chelating agents. Sci. Agric. 70, 290-295. http://dx.doi.org/10.1590/S010390162013000400010.

Srinieng, K., Saisavoey, T., Karnchanatat, A., Rasheed, A., Hameed, A., Khan, M.A., Mahmood, T., 2015. Effect of salinity stress on antioxidative enzyme activities in tomato cultured in vitro. Pakistan J. Bot. 47, 1-10.

Stolfa, I., Maronić, D.Š., Pfeiffer, T.Ž., Lončarić, Z., 2016. Glutathione and related enzymes in response to abiotic stress. In: In Redox State as a Central Regulator of Plantcell Stress Responses. Springer International Publishing, pp. 183-211. http://dx.doi. org/10.1007/978-3-319-44081-19.

Szabados, L., Savouré, A., 2010. Proline: a multifunctional amino acid. Trends Plant Sci. 15, 89-97. http://dx.doi.org/10.1016/j.tplants.2009.11.009.

Tari, I., Csiszár, J., Horváth, E., Poór, P., Takács, Z., Szepesi, Á., 2015. The alleviation of the adverse effects of salt stress in the tomato plant by salicylic acid shows a time-and organ-specific antioxidant response. Acta Biologica Cracoviensia Botanica 57, 21-30. http://dx.doi.org/10.1515/abcsb-2015-0008.

Wang, R., Jing, W., Xiao, L., Jin, Y., Shen, L., Zhang, W., 2015. The rice high-affinity potassium transporter1;1 is involved in salt tolerance and regulated by an MYB-type transcription factor. Plant Physiol. 168, 1076-1090. http://dx.doi.org/10.1104/pp. 15.00298.

Wang, J., Zhu, J., Zhang, Y., Fan, F., Li, W., Wang, F., Zhong, W., Wang, C., Yang, J., 2018. Comparative transcriptome analysis reveals molecular response to salinity stress of salt-tolerant and sensitive genotypes of indica rice at seedling stage. Sci. Rep. 8, 1-13. http://dx.doi.org/10.1038/s41598-018-19984-w.

Yasar, F., Uzal, O., Yasar, O., 2016. Antioxidant enzyme activities and lipidperoxidation amount of pea varieties (pisumsativum sp. arvense 1.) under salt stress. Fresenius Environ. Bull. 25, 37-42.

Zare, S., Pakniyat, H., 2012. Changes o antioxidant enzymes in oilseed rape in response to salinity stress. International Journal of Agricultural and Crop Sciences 4, 398-403.

Zouari, M., Elloumi, N., Ahmed, C.B., Delmail, D., Rouina, B.B., Abdallah, F.B., Labrousse, P., 2016a. Exogenous proline enhances growth, mineral uptake, antioxidant defense and reduces cadmium-induced oxidative damage in young date palm (Phoenix dactylifera L.). Ecological Enginnering 86, 202-209. http://dx.doi.org/10.1016/j ecoleng.2015.11.016.

Zouari, M., Ahmed, C.B., Elloumi, N., Bellassoued, K., Delmail, D., Labrousse, P., Abdallah, F.B., Rouina, B.B., 2016b. Impact of proline application on cadmium accumulation, mineral nutrition and enzymatic antioxidant defense system of Oleaeuropaea L. cv Chemlali exposed to cadmium stress. Ecotoxicol. Environ. Saf. 128, 195-205. http://dx.doi.org/10.1016/j.ecoenv.2016.02.024. 